\title{
E \\ The Conduct of Nuclear Hostilities
}

\section{Persons Who Participate}

\section{Rule 21}

The law of armed conflict does not prohibit any category of person from

participating in hostilities, including nuclear hostilities. The legal consequences of such participation will depend on the nature of the armed conflict and on the status of the individual concerned.

1 The customary law of armed conflict (LOAC) does not prohibit any class of individuals from taking a direct part in hostilities in an international or noninternational armed conflict. While Article $43(2)$ of API classifies members of the armed forces of a party to an international armed conflict, other than medical and religious personnel, as combatants and provides that combatants have the right to participate directly in the hostilities, there is no inference that persons who are not combatants are prohibited from taking part. $^{1}$

2 Combatants, however, are immune from prosecution for their acts of war that comply with LOAC. Combatant status does not apply to noninternational armed conflicts. Combatants, and certain other classes of individual, are entitled to prisoner-of-war status if captured by the enemy during an international armed conflict. Moreover, combatants are liable to be made the object of attack throughout the entire duration of an armed conflict, while persons other than combatants who take a direct part in hostilities are liable to be made the object of attack only during periods of such direct participation. Where relevant, these matters will be discussed further in connection with the following Rules in this Section.

1 Moreover, a person who does not satisfy the requirements for combatant status but who nevertheless takes a direct part in hostilities does not, without more, commit a war crime. 


\section{Combatants}

\section{Rule 22}

During an international armed conflict, members of the armed forces of a party to the conflict other than medical and religious personnel are combatants; that is to say, they have the right to take a direct part in the hostilities, including in nuclear operations.

1 For States that are not parties to API, customary law entitlement to combatant status is specified in Article 1 of the Hague Regulations. ${ }^{2}$ Article $4 \mathrm{~A}(1)$ and (2) of Geneva Convention III applies similar standards when determining entitlement to prisoner-of-war status for combatants. Combatancy and prisoner-of-war status apply only during international armed conflicts. There is no corresponding status during non-international armed conflicts.

2 Combatants who have taken part in hostilities, including nuclear operations, are entitled to prisoner-of-war status from the moment they fall into the hands of an adverse party to the conflict. ${ }^{3}$ Their entitlement to combatant immunity ${ }^{4}$ means that they may not be prosecuted for their hostile activities that comply with LOAC. Accordingly, if a combatant participates in the use of a nuclear weapon, he or she will be liable to prosecution before an international or domestic court only if the use of the nuclear weapon constituted a war crime, a crime against humanity or genocide.

3 For States that are not parties to API, members of the armed forces of a State that is a party to an armed conflict, including members of militias and volunteer corps that are part of such armed forces, are combatants. In addition, members of other militias or other volunteer corps and members of organised resistance movements that belong to a party to the

2 Article 1 states:

The laws, rights, and duties of war apply not only to armies, but also to militia and volunteer corps fulfilling the following conditions:

1. To be commanded by a person responsible for his subordinates;

2. To have a fixed distinctive emblem recognizable at a distance;

3. To carry arms openly; and

4. To conduct their operations in accordance with the laws and customs of war.

In countries where militia or volunteer corps constitute the army, or form part of it, they are included under the denomination "army".

3 GCIII, Article $4 \mathrm{~A}$.

4 Combatant immunity derives from customary law and thus applies to all States; see API, Article 43(2). 
international armed conflict also have combatant status if they fulfil four conditions, namely:

they must be commanded by a person responsible for his or her subordinates;

they must wear a fixed distinctive sign or uniform recognisable at a distance; they must carry their arms openly; and

they must conduct their operations in accordance with LOAC. ${ }^{5}$

The members of irregular forces that meet these conditions qualify as combatants, enjoy combatant immunity, have the right to participate in lawful nuclear operations during an international armed conflict and have the right to prisoner-of-war status if they are captured during such a conflict. Members of armed forces of States that are party to an international armed conflict are assumed to meet the four stated criteria and thus to have combatant status. Members of such forces that are assimilated to the armed forces have combatant status at customary law only if the armed group meets the four criteria.

4 Members of armed groups assimilated to the armed forces of a party to an international armed conflict satisfy the requirement of 'belonging to' a party to the conflict if a 'de facto' relationship exists between the organised group and the party to the conflict. No overt or public declaration of the relationship is necessary. It suffices if a tacit agreement or conduct makes it clear for which party the members of the group are fighting. ${ }^{6}$ Consider a situation in which a State uses the services of a group of private persons to undertake particular tasks connected with the use of nuclear weapons, for example, because members of the group have skills that are required in connection with the employment of the nuclear weapons. By virtue of a State's use of those services, the group is regarded as belonging to the State, so the members of the group will have combatant status if the group fulfils the other requirements set out earlier. Hence, 'belonging to a Party to the conflict' is an essential requirement; if it is not met, the group cannot have combatant status.

5 There is an essential link between the group being commanded by a person responsible for his or her subordinates and the 'organised' character of the group. This is normally not an issue in relation to either State armed forces or firmly established armed groups. The 'fixed distinctive sign' requirement is normally met by the wearing of a uniform. While Article 44(3) API

5 Hague Regulations, Article 1.

6 ICRC, Interpretive Guidance on the Notion of Direct Participation in Hostilities under International Humanitarian Law, ed. N. Melzer (May 2009) (ICRC Interpretive Guidance), 23. 
provides an exception to the rule for the 174 States that are parties to that treaty, that exception does not reflect customary law and therefore does not bind States that are not parties. However, it can be argued that in situations where combatants are located within a military object that in turn is required to bear military and nationality markings, such as a military aircraft or warship, there is no specific requirement for personnel on board to wear uniform or a fixed distinctive sign. ${ }^{7}$

6 The 'carrying arms openly' aspect refers to the obligation to carry personal weapons openly and does not relate to the carriage of nuclear weapons. The obligation of compliance with LOAC applies to the group as a whole. The fact that individual members of the group occasionally fail to comply does not deprive the group as a whole of combatant status, provided that the group as a whole generally complies. Those individuals who fail to comply will be liable to trial for any war crimes they have committed.

7 Paramilitary and law enforcement agencies may be incorporated by a State into its armed forces. ${ }^{8}$ Other parties to the international armed conflict must be notified if this is done, but if the incorporating State fails to notify other States, that does not mean that the members of the relevant agencies remain civilians. ${ }^{9}$ Once incorporation has taken place, the members of the relevant agencies have the right to take a direct part in hostilities, while retaining the right to perform their normal paramilitary or law enforcement duties, but are liable to be made the object of enemy attack so long as the armed conflict continues. ${ }^{10}$ If there is no such incorporation, the members of the agency have no right to participate in the hostilities.

8 Members of armed groups that do not fulfil the requirements set forth in the preceding paragraphs of this Commentary do not qualify for combatant status under customary law. If they nevertheless take a direct part in the hostilities, they will have no combatant immunity; they will be liable to be prosecuted for all their hostile acts, including those which comply with LOAC; and, if captured, they will have no right to prisoner of war status. If, however, such persons come within Article $4 \mathrm{~A}(4)$ or (5) of Geneva Convention III, they will retain prisoner-of -war status, but will be liable to be tried for the offences they have committed.

9 The notion of combatancy does not apply in non-international armed conflicts. In most circumstances, applicable domestic law and international

7 Consider AMW Manual, Commentary accompanying Rule 117. The danger in not wearing uniform is that if such persons become separated from the aircraft or ship and are thereafter captured, they are at risk of being treated as spies.

8 API, Article 43(3).

9 AMW Manual, Commentary accompanying Rule 10.

10 Unless they are rendered hors de combat, on which see Commentary to Rule 27 below. 
human rights law will apply and the former will determine whether prosecution is legally possible and appropriate.

10 For States that are parties to API, Article 43(1) defines the armed forces of a party to an international armed conflict as consisting of 'all organized armed forces, groups and units which are under a command responsible to that Party for the conduct of its subordinates, even if that Party is represented by a government or an authority not recognized by an adverse Party'. It adds that "[s]uch armed forces shall be subject to an internal disciplinary system which, inter alia, shall enforce compliance with' LOAC. Article 43(2) then designates such members of the armed forces, other than medical personnel and chaplains, as combatants, with the consequence that they have the right to participate directly in hostilities'. Incorporation of paramilitary or law enforcement agencies into the armed forces is then provided for in Article 43(3).

11 Article 44(1) stipulates that any combatant who falls into the power of the enemy 'shall be a prisoner of war' and, in order to promote civilian protection, Article 44(3) sets forth the obligation of combatants to distinguish themselves from the civilian population while engaged in an attack or in a military operation preparatory to an attack. ${ }^{11}$ This will usually involve wearing uniform or a fixed, recognisable emblem and will also usually involve carrying their weapons openly. However, Article 44 makes special provision in respect of difficult situations of combat, which were originally intended to apply in certain guerrilla warfare situations. If, in the relevant situations, an armed combatant cannot distinguish him- or herself, combatant status is retained if the combatant carries arms openly 'a) during each military engagement, and b) during such time as he is visible to the adversary while he is engaged in a military deployment preceding the launching of an attack in which he is to participate'. ${ }^{12}$ This circumstance is unlikely to arise in connection with the actual use of a nuclear weapon. However, consider a situation in which special forces personnel from State A have been instructed to attack the nuclear missile launching facility operated by State B during an ongoing armed conflict between the two States. State B has extensive security arrangements in place to protect the relevant facility. State A's special forces do not wear uniform or any identifying emblem at any time during the operation. Were they to do so, the base security personnel would shoot them on sight. While they are concealed in the thick forest surrounding the facility, their personal weapons remain concealed. However, as they break cover, they carry their

1 API, Article 44(3), first sentence.

12 API, Article 44(3), second sentence. 
weapons openly as they approach and scale the perimeter fences and then approach the part of the facility that is the target of the operation. By carrying their arms openly from the point when they would be visible to the adversary and throughout the military engagement, they have distinguished themselves for the purposes of the rule in the second sentence of Article 44(3).

12 Medical and religious personnel are non-combatants. ${ }^{13}$ They must be respected and protected, ${ }^{14}$ and must not be made the object of attack unless, and for such time as, they are used to commit, outside their humanitarian function, acts that are harmful to the enemy. ${ }^{15}$

\section{Naval and Air Warfare}

\section{Rule 23}

In naval and aerial warfare, the exercise of belligerent rights, including nuclear operations, is limited to warships and military aircraft as defined in international law. This Rule does not apply in situations of non-international armed conflict extending to international airspace or to sea areas beyond the outer limit of the territorial sea.

1 During an international armed conflict, naval operations will regularly occur in sea areas beyond the outer limits of the territorial sea of the parties to the conflict (i.e. in high sea areas which continue to be used by the ships of other States). Therefore, and because of the prohibition of privateering in the 1856 Paris Declaration, the right to exercise belligerent rights is strictly limited to warships. ${ }^{16}$

2 'Warship' means 'a ship belonging to the armed forces of a State bearing the external marks distinguishing such ships of its nationality, under the command of an officer duly commissioned by the government of that State and whose name appears in the appropriate service list or its equivalent, and manned by a crew which is under regular military discipline' ${ }^{17}$ Warships include surface and subsurface platforms. Accordingly, a submarine that fulfils these criteria is entitled to launch lawful attacks, including lawful nuclear attacks. At the same time, warships are military objectives by nature.

13 API, Article 43(2).

14 GCI, Article 24; GCII, Article 36.

5 AMW Manual, Rule 74(a).

16 US DoD Law of War Manual, para. 13.3.3; German Manual, para. 1019; San Remo Manual, Explanation accompanying Rule 13, para. 13.21.

17 UNCLOS, Article 29; San Remo Manual, para. 13(g). 
3 Ships not fulfilling the above criteria do not qualify as warships and are not entitled to exercise belligerent rights. Ships belonging to the armed forces of a State but under the control of a civilian master are auxiliary vessels and as such are prohibited to exercise belligerent rights. ${ }^{18}$ The same holds true for any other vessels, such as police or merchant vessels. It is a matter of ongoing debate whether unmanned maritime systems/vehicles which naturally lack a crew under regular military discipline are to be considered, or assimilated to, warships if they belong to the armed forces of a State, are marked as such and are under the control of a duly commissioned officer. The present authors are of the view that the presence of a crew is not absolutely required and that, therefore, unmanned maritime systems/vehicles may qualify as warships and be used for all operations at sea, including nuclear operations. It may be added that a (nuclear) torpedo is a platform that is not usually recoverable, is not therefore a warship and is therefore classed as a means of warfare.

4 Air operations during an international armed conflict will usually occur in, or extend to, international airspace that continues to be used by the aircraft of other States. Accordingly, the same considerations regarding ships apply to aircraft. According to customary law, the exercise of belligerent rights, including the launch of a nuclear missile, is strictly limited to military aircraft. ${ }^{19}$

5 'Military aircraft' means 'any aircraft (i) operated by the armed forces of a State; (ii) bearing the external markings of that State; (iii) commanded by a member of the armed forces; and (iv) controlled, manned or preprogrammed by a crew subject to regular armed forces discipline'. ${ }^{20}$ Accordingly, there is no requirement for the aircraft to have human operators on board, so unmanned aerial vehicles (UAVs) qualify as military aircraft if the elements of the definition are fulfilled, and they are therefore entitled to launch lawful attacks, including nuclear attacks. As in the case of warships, a distinction must be made between usually recoverable platforms, on the one hand, and means of warfare, such as (nuclear) missiles, on the other.

6 The limitation of the exercise of belligerent rights to warships and military aircraft, as defined, does not apply in situations of non-international armed conflict. $^{21}$

18

19 para. 17.

$2 \circ$ AMW Manual, para. $1(\mathrm{x})$.

${ }^{21}$ US DoD Law of War Manual, para. 13.3.3.1; AMW Manual, Commentary accompanying Rule 17, para. 7. 


\title{
Mercenaries
}

\begin{abstract}
Rule 24
A mercenary who is involved in nuclear operations does not enjoy combatant immunity and, in the event of capture by the adverse party in an international armed conflict, is not entitled to prisoner-of-war status.
\end{abstract}

1 For LOAC purposes, a mercenary is defined in Article 47 of API. At customary law mercenaries are not entitled to combatant privileges, ${ }^{22}$ but combatancy does not apply to non-international armed conflicts.

2 Article $47(2)$ of API defines a mercenary as a person who fulfils six cumulative conditions, namely:

(a) is specially recruited at home or abroad in order to fight in an armed conflict;

(b) does, in fact, take a direct part in the hostilities;

(c) is motivated to take part in the hostilities essentially by the desire for private gain and, in fact, is promised, by or on behalf of a Party to the conflict, material compensation substantially in excess of that promised or paid to combatants of similar ranks and functions in the armed forces of that Party;

(d) is neither a national of a Party to the conflict nor a resident of territory controlled by a Party to the conflict;

(e) is not a member of the armed forces of a Party to the conflict; and

(f) has not been sent by a State which is not a party to the conflict on official duty as a member of its armed forces.

3 If any one of the stated criteria does not apply, the individual is not a mercenary. However, if a person is, for example, recruited by a party to an armed conflict to discharge a particular technical role that is directly related to the use of a nuclear weapon and if that person, say, is paid significantly more than members of the party's own armed forces who are similarly employed, the individual in question is at risk of mercenary classification if the remaining conditions listed above are met. Compare this with the situation where there is no similarly employed member of the State's own armed forces, for example, because the State's own armed forces lack personnel with the relevant skills and/or experience. In such circumstances, the mere facts that the individual is motivated by gain, has been specially recruited in connection with an armed conflict and fulfils the other listed criteria do not cause the individual to be

22 UK Manual, paras. 4.10-4.10.4; Canadian Manual, para. 319; German Manual, para. 303; ICRC Customary Law Study, Rule 108. See, however, US DoD Manual, para. 4.21, according to which a mercenary cannot be denied combatant status in all circumstances. 
classed as a mercenary, because there is no person with a similar function in the State's own armed forces.

\section{Civilians}

\section{Rule 25}

Civilians comprise all persons who are neither combatants nor noncombatants, or who are not members of a State or non-State organised armed group. Civilians are not prohibited from taking a direct part in nuclear operations that amount to hostilities but may be made the object of attack for such time as they do so.

1 Article 51 API defines 'civilians' in negative terms as meaning all persons who are neither combatants nor non-combatants (i.e. who are neither medical nor religious personnel). ${ }^{23}$ The term 'combatants' includes members of a levée en masse. ${ }^{24}$ As the notion of civilians spontaneously taking up arms to resist an invading force would appear to have little or no relevance to nuclear weapon operations, it is not discussed further here, other than to note that, when assessing the compliance of a planned attack with the proportionality rule (see Rule 38), the participants in any levée en masse that may be taking place in the target area will not count as civilians during such time as the levée en masse is in progress.

2 The definition of civilians set forth in paragraph 1 is consistent with the provisions of Geneva Conventions III and IV. It follows that when nuclear targeting decisions are made in connection with an international armed conflict, civilians consist of all persons who are not members of the armed forces or of groups assimilated to the armed forces and who are not members of a levée en masse.

3 The treaty law of non-international armed conflict does not provide a negative definition of 'civilian'. However, it follows from the constitutive elements of the concept of non-international armed conflict that members of governmental or non-State organised armed groups taking part in such conflicts must be distinguished from civilians. According to the ICRC, however, those members of a non-State organised armed group who are not performing a continuous combat function qualify as civilians. ${ }^{25}$ The present authors are

23 See Commentary accompanying Rule 22 above.

24 A levée en masse refers to a situation in which ' $\mathrm{t}$ ]he inhabitants of a territory which has not been occupied, ... on the approach of the enemy, spontaneously take up arms to resist the invading troops without having had time to organize themselves in accordance with Article 1'. They are regarded as 'belligerents if they carry their arms openly and if they respect the laws and customs of war'. Hague Regulations, Article 2.

25 ICRC Interpretive Guidance, $27 \mathrm{ff}$. 
willing to agree with such a distinction, if it is limited to a non-State organised group that has political and military wings. Then, only the members of the military wing may be considered non-civilians, whereas those belonging to the political wing qualify as civilians. The criterion does not apply to the members of the military wing, however.

4 LOAC does not prohibit civilians from taking a direct part in nuclear hostilities connected with an international or non-international armed conflict. The legal consequences of such direct participation are that the civilians concerned lose their protection from being made the object of attack for the duration of their direct participation and, if captured, are liable to be prosecuted for whatever violent acts they may have committed or participated in. Such participation does not cause the relevant civilians to lose their civilian status, however.

5 The effect of the points made in paragraph 3 above is that if, say, a civilian is employed in deciding which location should be made the object of a nuclear attack, that civilian can be targeted during the period of that activity, and if that civilian were to be captured by the adverse party, he or she could be prosecuted and punished for his or her role in the nuclear operations.

6 For purposes of completeness, although the use of nuclear weapons in connection with a non-international armed conflict would seem highly unlikely, the absence of combatant status in such conflicts means that civilians are regarded as being all persons who are not fighters. Fighters consist of members of a State's armed forces, members of dissident armed forces and members of other organised armed groups.

7 Civilians other than those who are directly participating in hostilities must not be made the object of attack. Moreover, they are protected by the rules on indiscriminate attack, the proportionality rule and the rules on precautions in attack and precautions against the effects of attacks.

\title{
Doubt as to the Status of Persons
}

\author{
Rule 26 \\ In case of doubt as to whether a person is a civilian, that person \\ shall be considered to be a civilian.
}

1 This is a customary rule, ${ }^{26}$ based on the second sentence of Article $50(1)$ API. It is binding on all States and applies in both international and non-international armed conflicts. However, in the opinion of the authors,

26 Consider AMW Manual, Commentary accompanying Rule 12a; ICRC Customary Law Study, Commentary accompanying Rule 6; UK Manual, para. 5.3.1; Canadian Manual, para. 429 . 
the Rule 47 obligation on States in control of territory to take precautions against the effects of attacks is a factor that attackers are entitled to take into account when deciding whether there is in fact doubt such as to involve the application of the present Rule.

2 The degree of doubt that must arise for this Rule to apply is not clear. While the UK interpretation is that substantial doubt must still remain after assessing the information from all sources that is reasonably available at the relevant time ${ }^{27}$ reasonable doubt has been cited as the threshold in the context of a war crimes prosecution. ${ }^{28}$ In the opinion of the present authors, the doubt must be such as would cause a reasonable decision-maker to call off the planned nuclear attack or attack on a nuclear facility. Relevant factors would seem to include the nature, location and military importance of the target; the overall military situation; the size and characteristics of the weapon to be used; the numbers of persons expected to be affected and the degree of doubt as to the status of those persons; and whether there is an alternative target upon which an attack would be likely to accomplish the desired military purpose.

3 The Rule applies when there is doubt as to whether the persons are combatants or civilians. It has no application to a situation where doubt exists as to whether civilians are taking a direct part in hostilities. In the latter case, there is no presumption at law. The decision-maker must consider all of the information that is reasonably available at the relevant time and must reach a decision that is reasonable in all the circumstances.

4 In a non-international armed conflict, if there is significant doubt as to whether a person is a fighter or a peaceable civilian who is protected from attack, application of the principle of distinction requires that he or she is presumed to be a protected civilian.

\section{Persons Who May Be Made the Object of Nuclear Attack}

\section{Rule 27}

Members of the armed forces, members of organised armed groups, civilians taking a direct part in hostilities and, during an international armed conflict, participants in a levée en masse may be made the object of an attack, including a nuclear attack.

1 This Rule is based on the customary practice of States. LOAC is generally expressed as prohibitions. The fact that treaty law contains no express

27 Statements made by the United Kingdom on ratification of API on 28 January 1998, para. (h); UK Manual, para. 5.3.4.

28 Galić Trial Chamber Judgment, para. 55. 
permissions of the kind reflected in this Rule does not detract from the general practice of States, recognised as law, that certain categories of person, as listed in the Rule, may be made the object of attack during an armed conflict. ${ }^{29}$ It is their status as members of the armed forces or organised armed groups that renders attacks on them lawful, whereas, in the case of civilians who directly participate in the hostilities, it is their conduct that has a like effect. However, the use of a nuclear weapon to undertake such an attack would raise the grave concerns to which reference is made in Section A. The terms in which the present Rule and Commentary are expressed should not be misinterpreted as detracting in any way from those concerns.

2 For the purposes of this Rule, 'members of the armed forces' comprise the persons referred to in paragraphs 3 and 10 of the Commentary to Rule 22. However, medical and religious personnel and persons who are recognised, or in the circumstances should be recognised, as being hors de combat must not be made the object of attack. ${ }^{30}$

A person is hors de combat if:

(a) he is in the power of an adverse party;

(b) he clearly expresses an intention to surrender; or

(c) he has been rendered unconscious or is otherwise incapacitated by wounds or sickness, and therefore is incapable of defending himself;

provided that in any of these cases he abstains from any hostile act and does not attempt to escape. ${ }^{31}$

The authors consider that this definition now reflects customary law. Accordingly, it would be unlawful, for example, to make a large group of combatants who have fallen into the hands of an adverse party to the conflict the object of any attack, nuclear or conventional.

3 The members of organised armed groups referred to in the Rule are those with a combat function or who are members of the military wing of a non-State organised armed group. Persons who are members of such groups but whose functions do not involve combat - say, because they are exclusively concerned with diplomatic, administrative or social activities on behalf of the

29 The Tallinn Manual reaches a similar conclusion based on negative implication from other Rules. The present authors consider that while the inferences from the negatively expressed LOAC rules can properly be drawn, there is actually a positive permission to attack the listed categories of person based on customary law.

30 GCI, Articles 24, 25; API, Article 41; US DoD Law of War Manual, para. 5.10, UK Manual, para. 5.6; Canadian Manual, para. 309; German Manual, para. 6o1; AMW Manual, Rule 15 (b); NIAC Manual, paras. 2.3.2, 3.2; ICRC Customary Law Study, Rule 87.

${ }^{31}$ API, Article 41(2). 
group - should be accorded civilian status and are therefore protected from attack so long as they continue to have no combat function. If, therefore, an organised armed group comprises political as well as military elements, it is only the military elements that may be made the object of attack, including nuclear attack.

4 The situation of civilians who participate directly in hostilities is dealt with under Rule 28. In principle, civilian employees of contractors to the armed forces enjoy protection as civilians, unless and for such time as they directly participate in the hostilities. There is a controversy over whether a company that contracts with a party to the conflict to undertake particular kinds of military operation consequently qualifies as an organised armed group. The authors take the view that those members of the company that are involved in activities that amount to direct participation in hostilities may be made the object of attack throughout the period of such activity, and that facilities that are used for such purposes are likely to be military objectives in accordance with Rule 34. Whether a contractual relationship is sufficient in itself for a company to be regarded as an armed group belonging to a party to the conflict is legally uncertain and is likely to be of limited practical relevance in nuclear targeting. However, civilian persons - whether civil servants of the State or employees of a company - who are involved in the conduct of nuclear operations will be targetable by the adverse party on the basis of that participation for as long as the participation continues.

5 While it seems unlikely that a levée en masse would be the object of a nuclear attack, it should nevertheless be noted that participants in a levée en masse may be made the object of attack, as they have the status of combatants for the duration of the levée.

\title{
Protection of Civilians
}

\author{
Rule $\mathbf{2 8}$ \\ Civilians are protected unless and for such time as they take \\ a direct part in hostilities.
}

1 This Rule is based on Article 51(3) of API and on Article 13(3) of APII; it applies as a rule of customary law to international and non-international armed conflicts. ${ }^{32}$ The Rule applies only to civilians. It does not apply to members of the armed forces or members of a levée en masse, nor to members

32 US DoD Law of War Manual, para. 5.9; UK Manual, paras. 5.3.2, 5.8; Canadian Manual, paras. 318, 1720; German Manual, para. 517; AMW Manual, chapeau to Section F; NIAC Manual, paras. 1.1.3, 2.1.1.2; ICRC Customary Law Study, Rule 6. 
of organised armed groups who have a combat function. Members of an armed group that does not qualify as an 'organised' armed group and members of an organised armed group that have no combat function (e.g. because they are exclusively employed on diplomatic and other non-military duties on behalf of the group) will both be classed as civilians.

2 The Rule refers to protection in general, because civilians who take a direct part in hostilities not only lose their protection from being made the object of attack but also cease to be considered as civilians when the discrimination principle and proportionality rules are being considered in respect of a planned attack. Moreover, precautions in attack are not required in respect of directly participating civilians.

3 There is controversy as to the exact meaning of 'direct part in hostilities'. API and APII give no guidance as to how the expression should be interpreted, and while the ICRC has published 'Interpretive Guidance' on the subject, that publication has been the subject of criticism by States and commentators. For present purposes, it suffices to say that, to qualify as direct participation in hostilities, the activity must have the intended or actual effect of adversely affecting the enemy's military activities or capabilities or of positively affecting the conduct of hostilities by a party to the conflict other than the enemy. So, in times of armed conflict, fulfilling a role that contributes directly to nuclear targeting and installing software designed to render a State's own nuclear command and control systems immune from cyber-attack will both amount to direct participation in hostilities. However, there must be a direct causal link between the civilian's activity and either the infliction of harm on the enemy or enhancing the ability of the civilian's own party to conduct hostilities. So, a civilian who has a merely peripheral role in nuclear weapon use (e.g. a role that is limited to servicing the command and control computers associated with a nuclear-armed missile system) is unlikely to be regarded as directly participating in the nuclear hostilities. By contrast, and again by way of examples, a civilian who prepares and loads targeting data for such a system, who controls the launch of such missiles or who commands such operations will be regarded as directly participating in such hostilities because of the direct causal link between the civilian's acts and the harm caused to the adverse party when the weapon impacts on the target. Finally, there must be a direct link between the civilian's action and the nuclear hostilities. ${ }^{33}$ This will often be evident from the nature of the target that the nuclear weapon is intended to engage. 
4 Activities that are widely accepted as amounting to direct participation in nuclear operations include acts that make nuclear attacks possible, such as designing a nuclear weapon specifically to be used against a known, previously identified target. Obtaining and collating intelligence information on which to base nuclear targeting decisions will be direct participation, whereas mere maintenance of equipment associated with nuclear operations is unlikely to amount to direct participation. There are no precise demarcation lines in this part of the law. Each situation must be considered by reference to all of the relevant aspects of the activity, but, in general, States would be well advised to avoid employing civilians in roles that are directly associated with the conduct of nuclear attacks.

5 A civilian who takes a direct part in nuclear hostilities may be made the object of attack throughout the duration of such direct participation. If the civilian participates directly in only an isolated act - which is unlikely to be the case in relation to nuclear operations - he or she will be targetable while actually performing the act, preparing to perform it, travelling to the place where it is to be performed and returning from that place to his or her normal civilian location. If the civilian's activity involves a sequence of acts, the authors consider that the civilian will be regarded as directly participating for the entire time span of the sequence of acts. So, for example, a civilian who is responsible for inserting target data into a nuclear armed rocket system and who inserts such data on a regular basis over a period of several months will be targetable throughout that period of several months on a twenty-four-hours-a-day, sevendays-a-week basis. It should, however, be noted that some commentators take the view that the 'for such time as' language in the Rule means that a civilian loses and regains protected status, respectively, at the beginning and end of each specific act of direct participation, thus creating what has been described as a 'revolving door' of protection. Those commentators would argue that, in the previous example, the civilian who undertakes nuclear weapon activities during the daytime would lose protection when leaving home to travel to the nuclear weapon facility and would regain protected status each evening upon arriving home. The authors reject this 'revolving door' of protection notion as impractical and, therefore, as not reflecting the law.

6 If there is doubt as to whether a civilian is taking a direct part in hostilities, the obligation for the attacker is to consider all reasonably available information before making a decision on attack. He or she may decide in favour of making an attack only if a reasonable decision-maker, possessing that information, would so decide. If it is not reasonable to decide in favour of an attack in the relevant circumstances, the attack, whether nuclear or conventional, should not proceed. 


\title{
Nuclear Targeting: Applying the Principle of Distinction
}

\section{Definition of Nuclear Attack}

\author{
Rule 29 \\ A nuclear attack is a nuclear operation that constitutes an act of violence \\ against the adverse party, whether in offence or defence.
}

1 This definition applies in both international and non-international armed conflicts and is based on Article 49(1) of API, which is considered to reflect customary law.

2 'Attack' is an important concept, as many rules of the law of targeting specifically apply to attacks. However, some rules of targeting law apply to the broader notion of military operations. Military operations, in this context, comprise military activities that do not involve the use of violence but that adversely affect the enemy. Non-violent operations that are also non-harmful, such as espionage or psychological operations, qualify neither as attacks nor as military operations.

3 'Acts of violence' are not limited to acts that release kinetic force. ${ }^{34}$ Chemical, biological and radiological attacks tend to have no kinetic impact on their targets, yet it is generally accepted that the rules on attack apply to them. ${ }^{35}$ A nuclear attack occurs if a nuclear weapon or other nuclear capability is used to cause injury or death to persons, or damage or destruction to objects. A nuclear attack also occurs if an act of violence, whether nuclear or conventional, has as its object a nuclear weapon or capability. The notion would therefore, for example, include a nuclear operation in which a nuclear explosion generates an electro-magnetic pulse in order to disable the enemy's command, control, communications and intelligence infrastructure. The principles and rules of the law of targeting will apply to any nuclear attack. Minimal damage or destruction will not be sufficient to characterise an event as an attack. However, death, injury, damage or destruction may be directly caused by the use of a nuclear capability or may be the indirect consequence of such use. Equally, death, injury, damage or destruction may be the consequence of an act of conventional violence directed at a nuclear weapon or capability. In either case, the death, injury, damage or destruction will cause the military operation to be classed as an attack, because the said effects are reasonably foreseeable.

34 Tallinn Manual 2.0, Commentary to Rule 92, para. 3.

35 Tallinn Manual 2.0, Commentary to Rule 92, para. 3; Prosecutor v. Tadić, International Criminal Tribunal for the Former Yugoslavia Case IT-94-1-A, Decision of 2 October 1995 on the Defence Motion for Interlocutory Appeal on Jurisdiction, paras. 120, 124. 
4 To constitute an attack, the violence must be directed against the adverse party. This notion extends to uses of nuclear or conventional force that are directed against lawful targets and to acts of nuclear violence that have as their object of attack civilians, civilian objects or other protected persons or objects belonging to the adverse party to the conflict. It also extends to attacks which, for whatever reason, cause little or no damage or injury to the objects or persons that were the object of the attack, but which occasion incidental damage or injury to other objects or persons. Equally, it also applies to attacks which are directed at protected persons or objects in the mistaken belief that they are lawful targets. The lawfulness of the act of violence is not a prerequisite for its classification as an attack. ${ }^{36}$ For these purposes, 'injury', as that word is used in the present Commentary, includes mental suffering that rises to the level of an injury but does not extend to anxiety, irritation or other similar nervous reactions. Of particular potential relevance in the context of military nuclear operations is the fact that acts or threats of violence whose primary purpose is to spread terror among the civilian population are explicitly prohibited. ${ }^{37}$ For the rule to be broken, three elements must be present. First, there must be either an act of violence, such as nuclear violence, or a threat thereof. Second, the primary purpose of the act or threat must be the causing of terror among civilians. Third, that purpose must relate to the civilian population in general (as opposed to a collection of individuals, for example). So, if a party to the conflict threatens to use a nuclear weapon against a populated area, and the chief purpose of issuing the threat is to cause terror to the population there, as it very likely would, then the rule in Article 51(2) will have been broken. ${ }^{38}$

5 A nuclear operation constitutes an act of violence if it would have caused death, injury, damage or destruction to the adverse party were it not for defensive measures that prevented the damaging and/or injurious effects.

\section{The Principle of Distinction}

\section{Rule 30 \\ The principle of distinction applies to military nuclear operations.}

1 The principle of distinction has its roots in the preamble to the St Petersburg Declaration, ${ }^{39}$ which asserts that the only legitimate object which States

$3^{6}$ Tallinn Manual 2.o, Commentary to Rule 92, para. 7.

37 API, Article 51(2).

$3^{8}$ Indeed, making such a threat would also likely be considered to conflict with the principle of distinction, as reflected in API, Article 48, and with the obligation to take constant care, as reflected in Article 57(1), and thus to breach a customary law rule binding on all States.

39 St Petersburg Declaration, 1868. 
should endeavour to accomplish during war is to weaken the military forces of the enemy'. ${ }^{\circ}$ In the judgment rendered by the International Court of Justice when it considered the lawfulness of the threat or use of nuclear weapons, the Court described the principle of distinction as one of two 'cardinal' LOAC principles. ${ }^{41}$

2 The modern and customary formulation of the principle is reflected in Article 48 of API, which provides: 'In order to ensure respect for and protection of the civilian population and civilian objects, the Parties to the conflict shall at all times distinguish between the civilian population and combatants and between civilian objects and military objectives and accordingly shall direct their operations only against military objectives. ${ }^{32}$ Arguably, many of the specific rules on attacks set forth in Articles 51-58 of API, the majority of which reflect customary law, are reflections and/or applications of this principle. ${ }^{43}$ The principle applies to nuclear operations undertaken in connection with international and non-international armed conflicts. It relates to the conduct of military operations which, it will be recalled, is a notion that is broader than attacks and comprises military operations that adversely affect the enemy.

3 How the principle applies in non-international armed conflicts is less straightforward. The obligation to distinguish between, on the one hand, members of the armed forces, members of dissident armed forces, members of organised armed groups and civilians who are directly participating in hostilities, collectively best referred to as 'fighters', and, on the other hand, peaceable civilians is clear. Less clear is whether there is a corresponding duty to distinguish between military objectives and civilian objects. Neither Article 3 common to the Geneva Conventions nor Article 13 of APII explicitly provides for protection of civilian objects during non-international armed conflicts. However, it is widely accepted that customary law does indeed provide such protection. ${ }^{44}$

${ }^{4}$ ICJ Nuclear Opinion, para. 78. In the following paragraph of its judgment, the ICJ described the principle as 'intransgressible'.

42 See also US DoD Law of War Manual, para. 5.3.2 and n. 16; UK Manual, paras. 2.5-2.5.3; Canadian Manual, para. 423; AMW Manual, Rule 10; NIAC Manual, para. 1.2.2; ICRC Customary Law Study, Rules 1, 7; San Remo Manual, para. 39; Rome Statute, Article 8(2) (b)(i)-(ii) and (e)(i)-(ii).

43 Note, for example, the reference to the very word 'distinction' in the definition of indiscriminate attacks in API, Article 51(4).

44 DoD Law of War Manual, para. 17.7. See also UK Manual, paras. 15.16, 15.16.1; ICRC Customary Law Study, Rule 10 and associated Commentary; NIAC Manual, para. 1.2.2, Tallinn Manual 2.0, Commentary accompanying Rule 93, para. 3. 
4 Not all operations directed against civilians are unlawful. Activities by the armed forces that do not cause harm (e.g. propaganda, psychological and certain cyber operations) are not prohibited by the principle of distinction. The present authors would not agree with the suggestion in the Tallinn Manual that ' $[o]$ nly when a cyber operation against civilians or civilian objects (or other protected persons and objects) rises to the level of an attack is it prohibited by the principle of distinction and those rules of the law of armed conflict that derive from the principle'. ${ }^{45}$ The present authors consider that the principle of distinction applies not only in the case of attacks but also in respect of military operations. ${ }^{46}$ Accordingly, if a military nuclear operation is intended, or may be expected, to have an adverse effect on the enemy that does not amount to death, injury, damage or destruction, the principle of distinction will apply.

5 The effect of the principle of distinction is that a nuclear operation that is intended, or may be expected, to have an adverse effect on the enemy will be unlawful if the object of the operation consists of civilians or civilian objects. Moreover, a nuclear attack will be unlawful if it is indiscriminate. For these purposes, a nuclear attack would be indiscriminate if it is not directed at a specific military objective. A nuclear attack would therefore be unlawful if the expected loss of civilian life and/or the damage to civilian objects would be excessive in relation to the military advantage anticipated from the attack. So, while a nuclear attack that targets a densely populated area may seem likely to stave off strategic defeat or to bring the war to an early end, such an attack will breach the principle of distinction and those involved in prosecuting it will be liable for prosecution as war criminals (on which, see Section $\mathrm{H})$.

\section{Prohibition of Attacking Civilians}

\section{Rule 31}

The civilian population and individual civilians must not be made the object of nuclear attack.

1 This Rule applies to persons the principle of distinction set forth in the previous Rule. It is based on customary law, as reflected in Article 51(2) of API and Article 13(2) of APII, and therefore binds all States in relation to

45 Tallinn Manual 2.0, Commentary accompanying Rule 93, para. 5.

$4^{6}$ Consider API, Articles 48, 51(1), 57(1). 
both international and non-international armed conflicts. ${ }^{47}$ Civilians are defined in Rule 25 and the civilian population refers to all persons classed as civilians. The presence within the civilian population of persons who do not come within the definition of civilians or of civilians who are taking a direct part in hostilities does not deprive the civilian population of its civilian character. ${ }^{4}$ The term 'nuclear attack' has the meaning given in Rule 29.

2 The object of a nuclear attack is, for the purposes of the present Rule, the person or, more likely, persons that the attack is intended to target. A civilian loses protection under this Rule if and for such time as he or she participates directly in hostilities.

3 If a nuclear attack is directed at both persons and objects, they will collectively constitute the object of the nuclear attack. So, for example, if a nuclear strike is intended to destroy a military facility, such as a military air base, but the nuclear fallout is also intended to kill or injure a civilian community living in the vicinity of the air base, then both the air base and the civilian community would be regarded as the 'object' of the nuclear strike, because the intended impact of the attack on each of them will amount to death, injury, damage or destruction and thus, in each case, will satisfy the requirements of an attack. If, however, a nuclear attack is directed at a military objective, such as a military air base, but also causes unintended, incidental injuries or deaths among the local civilian population, the affected civilians cannot be regarded as having been an 'object' of the attack, and the harm the civilians can be expected to suffer should be considered when the proportionality assessment discussed in Rule 38 is made.

\section{Terror Attacks}

\section{Rule 32}

An act or threat of nuclear violence the primary purpose of which is to spread terror among the civilian population is prohibited.

1 This Rule is based on the second sentence of Article 51(2) of API and the second sentence of Article 13(2) of APII. Accordingly, the Rule applies in international and non-international armed conflicts.

47 US DoD Law of War Manual, paras. 5.3, 17.7; UK Manual, paras. 2.5.2, 5.3; Canadian Manual, paras. 312, 423; German Manual, paras. 404, 502; AMW Manual, Rule 11; NIAC Manual, para. 2.1.1.1; ICRC Customary Law Study, Rule 1; Rome Statute, Article 8(2)(b)(i) and (ii), 8(2)(e)(i) and (ii).

$4^{8}$ API, Article 5o(2) and (3). 
2 The reference to an 'act or threat of nuclear violence' makes clear that the Rule applies to attacks and to threatened attacks with the stated primary purpose. The Rule therefore does not apply to acts or threatened acts that do not or would not constitute attacks ${ }^{49}$ (e.g. military activities that have an adverse effect on the enemy but do not involve the use or threat of violence). It is useful to consider two examples. First, a news report suggesting that the adverse party to the conflict is planning to undertake a nuclear attack would not breach this Rule, because the activity constitutes neither an act nor a threat of violence but, rather, a report, whether true or false. Second, a nuclear attack whose main purpose is to destroy a large military facility but which has the secondary effect of causing widespread panic among the civilian population will also not breach the Rule, this time because the panic or terror is not the primary purpose of the act of violence. Accordingly, it is the primary or main purpose of the act or threat of violence that is key in this Rule.

3 The intent must be to cause terror to a significant segment of the population. A primary purpose to cause terror to a group of individuals will not constitute a breach of this Rule. However, an act of violence directed against a single individual or a small group of individuals, but with the main purpose of causing terror to the population at large, will cause the Rule to be broken. It should also be noted that it is the civilian population as defined in paragraph 1 of the Commentary on Rule $3_{1}$ that is protected by this Rule. The Rule will not be breached if the main purpose of the act or threat is to cause terror among enemy combatants. ${ }^{\circ}$

4 A threat that breaches the Rule may be communicated by numerous means, including broadcasts or social media, email or more traditional written, telegraphic, telephonic or other means. There must, however, be the explicit communication of a threat. This is to be distinguished from deterrence policies, for example, where the possession and further development of nuclear weapon capabilities are designed to deter an adversary or potential adversary from undertaking hostile activity. Viewed from a legal perspective, deterrence consists of the visible maintenance of a state of military preparedness with the purpose of dissuading adversaries or potential adversaries from undertaking certain unwelcome action. The deterrence may or may not be directed at a specific State but - importantly, for present purposes - it does not take the form of a specific threat to use stated force against a named target on

49 Consider API Commentary, para. 1940; Tallinn Manual 2.0, Commentary to Rule 98, para. 2.

5० Tallinn Manual 2.0, Commentary accompanying Rule 98, para. 5. 
a particular occasion. No explicit threat is involved, so policies of nuclear deterrence that accord with this broad description do not breach this Rule.

5 Article 33 of Geneva Convention IV prohibits 'measures of intimidation or of terrorism' directed against persons protected by that Convention..$^{51}$ The prime terrorising purpose reflected in the Rule does not apply to Article 33 GCIV. Moreover Article 33 is not limited to acts or threats of violence. The present authors take the position that there are two distinct rules at play here. When interpreting Article 33, it must be remembered that the provision is limited in its application to situations governed by GCIV, whereas the broader Rule to which the present Commentary relates is more generally applicable to the protection of civilian populations.

\section{Prohibition of Attacking Civilian Objects}

\section{Rule 33}

Civilian objects shall not be made the object of attacks, including nuclear attacks. Civilian objects are all objects which are not military objectives.

1 The St Petersburg Declaration provided that 'the only legitimate objective which States should endeavour to accomplish during war is to weaken the military forces of the enemy'. ${ }^{2}$ The more modern formulation in Article 52(1) of API is reflected in the present Rule. The Rule has customary law status and applies in both international and non-international armed conflicts. The Rule extends to nuclear attacks as defined in Rule 29.

2 Civilian objects are defined in negative terms as being all objects which are not military objectives. Accordingly, all objects are either military objectives or civilian objects. There is no third category of object.

3 The directing of an attack against a civilian object is sufficient to breach this Rule, irrespective of whether the attack caused damage.

4 The first sentence of the Rule, which prohibits making a civilian object an object of attack, should be distinguished from the prohibition of indiscriminate attacks reflected in Rule 37. A breach of the present Rule arises when the attacker is aiming at a civilian object, whereas an indiscriminate attack occurs when an attack is not, or cannot be, directed towards a specific target.

51 Namely, those who, during a conflict or occupation, find themselves in the hands of a party to the conflict or occupying power of which they are not nationals, unless the State of which they are nationals has normal diplomatic representation in the State in whose hands they find themselves. GCIV, Article 4(1) and (2).

52 St Petersburg Declaration, preamble. 


\section{Definition of Military Objectives}

\section{Rule 34}

In so far as objects are concerned, military objectives are those objects which, by their nature, location, purpose or use, make an effective contribution to military action and whose total or partial destruction, capture or neutralisation, in the circumstances ruling at the time, offers a definite military advantage.

1 The Draft Hague Rules of Aerial Warfare defined 'military objective' as 'an object of which the destruction or injury would constitute a distinct military advantage to the belligerent'. ${ }^{53}$ The more modern conventional law formulation in Article 52(2) of API adopts the language that is reflected in the present Rule. The same language has been widely used by States in military manuals ${ }^{54}$ and reflects customary law applicable to international and non-international armed conflicts. The legal term 'military objective' has the precise meaning given in the Rule and is used throughout this book only in that sense. Where looser, operational concepts of military objectives are referred to, they will be described using suitable, but different, language.

2 The Rule relates only to objects. The legal status of persons during armed conflict is a separate matter that is dealt with in Rules 21, 22, 24, 25, 26, 27, 28 and 31. An object is something that is 'visible and tangible'. ${ }^{55}$ It does not therefore include more nebulous notions such as morale, confidence, political opinions or productivity.

3 An object may be qualified as a military objective, and thus as a lawful target for an attack, on the basis of any one of the four criteria given in the Rule. The 'nature' criterion refers to the inherent character of an object. It refers, for example, to objects that are fundamentally military and that are designed to contribute to military action. ${ }^{56}$ So, a nuclear weapon launch/delivery platform - warships, including submarines, (strategic) bombers and cruise missiles - as well as the nuclear weapons themselves would be obvious examples of objects that are military objectives by nature. Likewise, nuclear weapon command, control and communications facilities will also be military objectives by nature. Similar considerations apply when selecting targets for

53 Draft Hague Rules of Aerial Warfare, 1923, Article 24(1).

54 US DoD Law of War Manual, para. 5.7.3; UK Manual, para. 5.4.1; Canadian Manual, para. 406; German Manual, para. 442; AMW Manual, Rule 1(y); NIAC Manual, para. 1.1.4; ICRC Customary Law Study, Rule 8; San Remo Manual, Rule 40. See also Protocol II to CCW, Article 2(4); Protocol III to CCW, Article 1(3).

55 API Commentary, paras. 2007, 2008.

${ }_{56}$ API Commentary, para. 2020; see also Tallinn Manual 2.0, Commentary to Rule 100, para. 8. 
nuclear attack. Accordingly, military depots and facilities, including military airfields, naval ports, military redeployment sites and military bases are among the many examples of military objectives by nature. "The fact that civilians (whether government employees or contractors) may be operating these [facilities] is irrelevant to the question of whether they qualify as military objectives. ${ }^{57}$

4 The 'location' criterion refers to a place - usually a geographical feature that is of military importance..$^{8}$ An elevated piece of ground overlooking a plain or a mountain pass might be examples of locations that, in the context of the military operations taking place at the time or that are contemplated, constitute military objectives. The 'purpose' criterion refers to the intended future use of the object, whereas 'use' is concerned with the current use that is being applied to the object. So if, for example, the top of a civilian office block is being used by the enemy as an observation post from which to call in artillery fire, the current use of what otherwise would be a civilian object will render the office block a military objective. Likewise, if there is reliable information that the enemy intends to use a department store to accommodate troops and weapons, the department store will become a military objective now by virtue of that intended future use. Accordingly, civilian infrastructures (e.g. rail and other communications networks, radio and television stations, civilian airfields and ports) may well become military objectives either by virtue of their current use or their intended future use ('purpose'). Factories that produce equipment, clothing, weapons, ammunition and other supplies for military use will be military objectives by virtue of 'use'. While any provision of supplies for military purposes will, technically, render the supplying factory a military objective, whether such a facility should be attacked will depend, for example, on whether the military advantage anticipated to be gained from the attack outweighs the expected civilian injuries and damage (on which, see Rule $\left.3^{8}\right)$.

5 If an object is a military objective by use and all military use ceases, the object reverts to being a civilian object, with the consequence that the protection of the object from nuclear attack resumes. However, if the enemy intends to use the object again for military purposes, it will remain a military objective by virtue of that intended future use ('purpose'). The mere fact that an object was once used for military purposes does not necessarily, without more, mean that the enemy intends to use it again for such purposes. It may be

57 Tallinn Manual 2.0, Commentary to Rule 100, para. 8.
$5^{8}$ API Commentary, para. 2021. 
difficult to determine the enemy's intentions as to the future use of an object. The doubt rule, as reflected in Rule 36 , applies only in cases of doubt as to an object's current use. While no presumption in relation to intended future use applies, the attacker must act reasonably. If a reasonable decision-maker would find that the information reasonably available to the attacker is sufficient to support a conclusion that the civilian object is going to be used for military purposes, it will be appropriate for the attacker also to reach that conclusion.

6 The Rule requires that the object in question makes an effective contribution to military action. This means that the object must in some way directly support or contribute to the military activities of the enemy. If, however, a facility is only offering indirect support, this will not be sufficient for these purposes. Consider, for example, a television station that schedules programmes that are patriotic or that contain propaganda material. This alone will not cause the television station to become a military objective, with the result that it will remain a civilian object that is protected from attack.

7 Objects that satisfy the 'nature' criterion will be military objectives, save unusual circumstances, because they will be making an effective contribution to military action. In exceptional circumstances, such as when an object that had a military nature in some past era has become a cultural object, the object will be a civilian object, because, notwithstanding its nature, it no longer makes an effective contribution to military action and therefore does not fulfil the definition in the Rule. Only if an object makes an effective contribution to military action by virtue of its nature, location, purpose or use will its destruction, capture or neutralisation offer a definite military advantage. While the Rule sets forth a twin-pronged test, in practice an object that makes an effective contribution to military action will also be an object whose destruction, capture or neutralisation, in whole or in part, will offer a definite military advantage.

8 It should be noted that the United States holds that 'war-sustaining' objects can be military objectives. As the US DoD Law of War Manual explains:

Military action has a broad meaning and is understood to mean the general prosecution of the war. It is not necessary that the object provide immediate tactical or operational gains or that the object make an effective contribution to a specific military operation. Rather, the object's effective contribution to the war-fighting or war-sustaining capability of an opposing force is sufficient. Although terms such as 'war-fighting', 'war-supporting' and 'war-sustaining' 
are not explicitly reflected in the treaty definitions of military objective, the United States has interpreted the military objective definition to include these concepts. ${ }^{59}$

This approach would qualify as military objectives staple resources or products on which the enemy's economy is based and on which the enemy therefore relies to fund the war effort. A similar line of reasoning would also treat cash that is available for the payment of fighters or enemy combatants or that would be used to acquire weapons, ammunition or military equipment for enemy use as a military objective and thus as the lawful object of attack, including nuclear attack. At its broadest, this war-sustaining concept would render a military objective, and thus a lawful object of attack, any object that gives any support, however minimal, to the continuance of the war. The present authors consider that this goes too far, as the connection between the warsustaining object and military action is insufficiently direct and almost any enemy object can be expected to give a degree of support of some kind, however minimal, to the enemy's war effort. In the view of the present authors, objects become military objectives when they have a direct war-fighting or direct hostilities-supporting role. In the latter case, a facility is hostilitiessupporting if, for example, it produces objects or materials that are used by the armed forces, such as ammunition, military equipment or weapons. The distinction here is between a facility that makes, delivers or prepares objects that are to be used in the conduct of warfare and a facility that generates the financial, fiscal or economic capacity to carry on the armed conflict. The former element involves a direct link between the target and the military capability, whereas with the latter the link between the object and war fighting is indirect. The distinction explained in the current paragraph may appear to be a fine one but is nonetheless important, because it is the foundation of the protective effect of the cardinal and intransgressible principle of distinction.

9 The Rule makes it clear that the advantage must be military in nature. If attacking the object will produce only economic, political or psychological advantage, this will not be sufficient to cause the object to become a military objective. $^{60}$ It follows from this that an object the nuclear attack of which is only intended to make a political point to the adverse party's leadership or population will not satisfy the Rule and will not therefore be a military objective. The 'effective contribution' and 'advantage' aspects of the Rule are most important, and each must be military in nature.

DoD Law of War Manual, para. 5.7.6.2 (citations omitted).

6o Tallinn Manual 2.0, Commentary accompanying Rule 100, para. 21. 
10 This Rule is only concerned with whether the object in question can lawfully be made the object of an attack. Once that has been established, the Rules on indiscriminate attacks, proportionality and precautions, set forth respectively in Rules 37, 38, and 39-46, apply to any decision actually to undertake the attack.

11 Necessarily, the decision as to whether an object is a military objective is made before the attack occurs. The decision is based on the information that is reasonably available when the decision is being made and will be informed by the decision-maker's assessment of that information. The lawfulness of the attack can be properly assessed only by reference to the information then available. If enemy action causes the nuclear weapon, or the weapon that is being used to attack a nuclear weapon-related facility, to perform in a manner other than that intended when the attack was launched, this will not, of itself, call into question the lawfulness of the decision to undertake the attack.

\section{Dual-Use Objects}

\section{Rule 35 \\ An object that is used for civilian and military purposes is a military objective.}

1 This Rule makes it clear that an object which fulfils the requirements of the previous Rule is a military objective even if it is also used for civilian purposes. The civilian use does not exclude its classification as a military objective, although principles and rules as to indiscriminate attack, proportionality and precautions in attack will have to be complied with, as is the case with all attacks.

2 The proportionality rule may have particular relevance when dual-use objects are to be attacked. While the object in question will qualify as a military objective, any expected harm to civilian objects or any expected injury and/or death among civilians (collectively referred to as collateral damage) must be taken into consideration when the proportionality rule is being applied. Difficult and controversial legal issues arise if the object of an attack constitutes part of a composite structure. Consider, for example, a situation in which part of an apartment block or an individual structure within a cluster of buildings constitutes the object whose destruction or neutralisation will offer a definite military advantage. While the entire building will constitute a military objective, those involved in the conduct of the attack must take all feasible precautions to avoid, and in any event to minimise, death and injury to civilians and damage to civilian objects in the vicinity 
of the building. Thus, while the whole of the apartment block and the complete cluster of buildings would be regarded as the military objective, the indiscriminate attack, proportionality and precautions rules will apply and must be complied with scrupulously. It follows from this that the use of nuclear weapons against composite targets of the sort discussed in the present paragraph is in most circumstances likely to be unlawful, and this would be especially so if a more discriminating weapon is available that would achieve the intended military purpose.

\section{Doubt as to the Status of Objects}

\section{Rule 36}

If, after a careful assessment has been made, there remains substantial doubt about whether an object that is normally dedicated to civilian purposes is being used to make an effective contribution to military action, it must be assumed that it is not being so used.

1 This Rule applies in both international and non-international armed conflicts. The presumption probably binds only States that are parties to API. Article 52(3) of API provides that ' $[\mathrm{i}] \mathrm{n}$ case of doubt whether an object which is normally dedicated to civilian purposes ... is being used to make an effective contribution to military action, it shall be presumed not to be so used ${ }^{6}{ }^{61}$ The API provision and the Rule create a presumption that applies only where doubt as to use exists and only to the decision on whether an object is a military objective and, thus, whether it can lawfully be made the object of attack. The Rule does not apply where doubt arises in relation to the nature, location or purpose criteria in Rule 34 .

2 The formulation of the present Rule does not follow the API language exactly. States that are parties to API will be bound to apply Article 52(3) of the treaty as written. However, for States that are not parties to the treaty and for those that are parties but made interpretive statements to this effect, the Rule applies only if the doubt is substantial and if it persists after all reasonably available information has been considered. The language of the Rule therefore seeks to reflect the treaty language, adjusted so as to take account of certain statements made on ratification of API.

3 So, if doubt arises as to whether an object is being used for military purposes and therefore can be made the object of nuclear attack, the Rule requires that a careful assessment be made and stipulates that, if doubt still

61 Consider also Amended Protocol II to CCW, Article 3(8)(a). 
exists after that careful assessment, the object must not be made the object of attack, including nuclear attack. Given the potentially very serious consequences to be expected from a nuclear attack, it is sensible to conclude that this Rule should be applied most stringently to any attack involving nuclear capabilities. If, furthermore, the doubt is about whether, for example, a building is being used to accommodate a nuclear weapon, the collateral consequences that would be expected to arise from the attack may well also be very severe, such that a similarly high degree of caution will be required.

4. The Rule is a development of the widely accepted requirement that those who plan, decide upon or execute an attack must do everything that is practically possible to verify that the object of the attack is neither a civilian object nor subject to special protection, but is a military objective.

5 The Rule applies only if the object is normally dedicated to civilian purposes. If the object is also used for military purposes on anything more than rare, spasmodic occasions, it cannot be regarded as normally dedicated to civilian purposes. The careful assessment referred to in the Rule must be sufficiently thorough for it to be reasonable to conclude that the object is indeed being used for military purposes. That conclusion can properly be reached only by considering all of the information that is reasonably available; by assessing how reliable that information appears to be; by reflecting on how up to date the information is; by considering whether there is evidence of deception; and by seeking to ensure that all of the available information is interpreted correctly, both individually and collectively.

6 This decision does not require certainty. The proper test is whether, given what is known at the relevant time, a reasonable commander would conclude that the enemy is using the object in question to make an effective contribution to military action (e.g. by using the target object for military purposes). If a reasonable attacker would not hesitate before undertaking the attack, neither should the decision-maker. ${ }^{62}$

7 The Rule applies to decisions that are made in advance of an attack. Information that comes to light after the attack is not relevant to the application of this Rule if it was not available to those who planned, approved or executed the attack. It follows that an attacker complies with this Rule by taking all practically possible steps to determine the uses to which the object is being put and by determining that those uses include activity that makes an effective contribution to military action. For these purposes, the information which is reasonably available to the decision-maker will depend on the information gathering and processing systems that support the decision-maker

62 AMW Manual, Commentary accompanying Rule 12(b). 
or that support the functions he or she performs. Some States and some armed forces may have more access to timely and reliable information than others, and, to a degree, the particular decision that is made must be judged by reference to the information actually available to the specific decision-maker at the relevant time.

However, lack of access to information does not give a party to the conflict licence to 'fire blind'; the prohibition of indiscriminate attacks will continue to apply (on which, see Rule 37 below).

8 If the particular military use ceases, the object will revert to being a civilian object, unless it is being used in another way for military purposes or has become a military objective on some other ground, such as nature, location or purpose. Furthermore, States in control of territory have the duty to take feasible precautions against the effects of attacks, and this duty includes the application of distinctive marks to 'objects dedicated to religion, art, science or charitable purposes, historic monuments, hospitals, and places where the sick and wounded are collected'. ${ }^{6} 3$

\section{Indiscriminate Attacks}

\section{Rule 37}

Nuclear attacks that are not directed at a specific military objective and that, as a result, are of a nature to strike military objectives, civilians and civilian objects without distinction are prohibited.

1 Some of the ideas reflected in this Rule were first articulated in the Lieber Code, Articles 22 and 23. The modern formulation of the Rule is Article $51(4)(a)$ of API. The Rule applies in both international and noninternational armed conflicts, reflects customary law and therefore binds all States in relation to their use of all weapons, including nuclear weapons. ${ }^{64}$

2 This Rule prohibits nuclear attacks that, for whatever reason, are not directed at a specific lawful target. Common sense suggests that this may be because the weapon is incapable of being directed at a lawful target, ${ }^{6}$ or because the weapon's effects cannot be reasonably limited to the vicinity of a lawful target, ${ }^{66}$ or because the attacker simply fails to direct the weapon at

63 Hague Regulations, Article 27.

64 Consider Amended Protocol II to CCW, Article 3(8); US DoD Law of War Manual, para. 6.18; UK Manual, paras. 5.23-5.23.2; Canadian Manual, paras. 416, 613; German Manual, para. 404; AMW Manual, Rule 13; ICRC Customary Law Study, Rules 11, 12 and Commentary accompanying Rule 11; NIAC Manual, Rule 2.1.1.3; San Remo Manual, Rule 42b.

65 This proposition is based on API, Article $51(4)(\mathrm{b})$, and is a rule that reflects customary law.

66 This proposition is based on API, Article 51(4)(c), and is a rule that reflects customary law. 
a lawful target. If the attacker simply fails to direct a weapon, whether nuclear or conventional, at a lawful target and an indiscriminate attack results, there is general agreement that this will render the attack unlawful on that ground. The law is not so clear, however, where the application of Article 51(4)(b) and $51(4)$ (c) to nuclear weapons is concerned. When ratifying API, numerous NATO States made statements to the effect that the new rules introduced by the treaty would not apply in relation to nuclear weapons. ${ }^{67}$ While, as shown in paragraph 1 above, the prohibition of indiscriminate attacks was not a new rule introduced by the treaty, the extensions of that rule in subparagraphs (b) and (c) were, arguably, new and would not, therefore, apply to nuclear weapons for States that made the relevant statements. Arguably, therefore, while Articles 51(4)(b) and 51(4)(c) are customary law in their application to non-nuclear weapons, they do not have that status in relation to nuclear weapons. That said, these provisions do apply as a matter of treaty law to States that are parties to API and that made no statement on ratification of the sort referred to earlier in this paragraph.

3 Notwithstanding the legal complications set forth in the previous paragraph, indiscriminate attacks using nuclear weapons are prohibited, and the present authors take the view that, if the circumstances referred to in Article $51(4)($ b) or $51(4)$ (c) caused the attack to be indiscriminate, this will not prevent the resulting attack from being unlawful. So, if the attacker fires a nuclear weapon without taking suitable steps to direct it towards a specific lawful target, the indiscriminate attacks rule will have been broken. Sometimes, a weapon that is in principle capable of discriminating use might be used in circumstances which render its use indiscriminate. So, for example, if a nuclear weapon is equipped with laser guidance technology, that will often enable the weapon to be directed towards a specific target with considerable precision. It is well known that obscurants such as cloud, smoke, sandstorms, and the like will tend to impede the operation of the laser guidance technology and may render an attack indiscriminate. If the attacker, knowing that such conditions prevail in the target area, nevertheless proceeds with a nuclear attack with indiscriminate effects, the resulting attack will breach the Rule. Similarly, if the nuclear fallout or contamination caused by the attack cannot be controlled, and if it is known before the attack takes place that weather conditions in the target area can be expected to cause the nuclear fallout to spread so as to affect populated areas to such a degree as to render the attack

67 An example is the statement made by the UK on ratification of API on 28 January 1998; see Commentary accompanying Rule 64 below, para. 3 . 
indiscriminate, then the attack will breach the Rule and, thus, will be unlawful.

4 Indiscriminate attacks that breach the present Rule must be distinguished from attacks that are directed at protected persons or objects and that therefore, for example, breach Rule 54. It will be the individual circumstances of the particular attack that will determine whether it was indiscriminate. These circumstances will include the characteristics of the weapon that is used and of its guidance system; the nature and location of the target; the prevailing and forecast weather conditions; the nuclear command, control and communications arrangements; circumstances applying to the persons planning, commanding and undertaking the attack; and other relevant factors.

5 The mere fact that an indiscriminate attack is intercepted before a weapon, including a nuclear weapon, reaches its target does not affect the illegality of the attack. ${ }^{68}$

6 States that ratified API without making the 'nuclear statement' referred to in paragraph 2 are bound by a provision in Article 51(5)(a) that is stated there to be an example of an indiscriminate attack. The effect, for those States, of the provision's application to nuclear weapons is to prohibit nuclear attacks that treat as a single military objective a number of clearly separated and distinct military objectives that are located within a similar concentration of civilians or civilian objects. So, Article 51(5)(a) is concerned with a situation in which military objectives and civilian objects and/or civilians are co-mingled in such a way that it is nevertheless feasible to attack the military objectives individually. Accordingly, the API provision will apply where, for example, individual military objectives such as barracks, depots or ammunition factories are in different locations within a populated town and could be targeted individually. In such circumstances, States that are bound by Article 51(5)(a) in its application to nuclear weapons would be prohibited from using a nuclear weapon to target the town as a whole and would be required to treat the military objectives individually. What is separate and distinct for these purposes will depend on the circumstances. If available weapons would be capable of engaging the targets individually, then the targets can safely be regarded as separate and distinct for the purposes of the API provision. However, if any State - including States that made the nuclear statement upon ratifying API and those that are not parties to the treaty - were to use a nuclear weapon to attack the town in the stated

68 However, depending on the circumstances, it may be difficult to detect whether an attack that is intercepted at altitude would have had indiscriminate effects if completed. 
example, the attack would almost certainly be indiscriminate and thus unlawful if, as is assumed, it has the effect of striking civilian objects and military objectives without distinction.

7 Where nuclear weapons are concerned, it must be noted that the rule introduced in Article 51(5)(a) of API applies only to States that are parties to the treaty and that have not made statements excluding the application of the new rules introduced by API. It should also be stressed, however, that States that are not parties to API or that made the nuclear statement remain bound by the general prohibition of indiscriminate attacks set forth in the present Rule. If, through the kind of nuclear attack contemplated in Article 51(5)(a), an indiscriminate attack results, the present authors consider that the attack will be unlawful on that ground, notwithstanding the legal complications discussed here and in the previous paragraph.

8 For those States that are bound by the provision referred to in paragraph 6 in respect of nuclear weapons use, that provision applies independently of the proportionality rule (Rule 38). This means that a State that is a party to API and that did not make a nuclear statement must consider three legal rules in relation to indiscriminate nuclear attacks. The first rule is that discussed in paragraph 6. The second rule is the proportionality rule (Rule 38). The third rule is the general prohibition of indiscriminate attacks, given that attacks not covered by the first two provisions may nevertheless be indiscriminate.

\section{Proportionality}

\section{Rule $3^{8}$}

An attack, including a nuclear attack, that may be expected to cause incidental loss of civilian life, injury to civilians or damage to civilian objects, or a combination of those things, that would be excessive in relation to the anticipated concrete and direct military advantage is prohibited.

1 The basis for this Rule is Article 51(5)(b) of API. While the API provision is known as the proportionality rule, it will be noted that excessiveness is the key notion. The Rule applies in both international and non-international armed conflicts and, as a rule of customary law, binds all States. ${ }^{69}$ While the API

69 Second Protocol to the Hague Convention of 1954 for the Protection of Cultural Property in the Event of Armed Conflict, The Hague, 26 March 1999, Article 7; Amended Protocol II to CCW, Article 3(3); US DoD Law of War Manual, para. 6.18; UK Manual, paras. 5.23.2, 15.15.1; Canadian Manual, GL-5; AMW Manual, Rule 14 and accompanying Commentary; NIAC Manual, para. 2.1.1.4; ICRC Customary Law Study, Rule 14; API Commentary, para. 4772. 
provision is set forth in Article 51(5)(b) merely as an example of the kind of attack that is prohibited by virtue of being indiscriminate, in Article 57 of the treaty it is the proportionality rule that must be one of the key focuses of the precautions that attackers must take. The precautionary rules are set forth in Rules 39-46 below.

2 The focus of the present Rule is situations in which attacks cause incidental harm to civilians and/or civilian objects. The intended object of attack will have been a lawful target (i.e. a military objective, combatants or directly participating civilians), but attacking that target also involves the danger that civilians and/or civilian objects will suffer injury or damage, collectively referred to in the remaining paragraphs of this Commentary as 'collateral damage'. The mere likelihood that collateral damage will arise as a result of an attack on a lawful target does not, per se, render the attack unlawful. It is only when the expected collateral damage is excessive when compared with the anticipated military advantage that this Rule would be broken were the attack to take place. ${ }^{70}$

3 It is the collateral damage reasonably expected by the attacker that must be considered. However, certain effects of attacks affecting civilians fall below notions of collateral damage and therefore do not have to be considered for these purposes by the attacker. These effects include fear, inconvenience, irritation, worry and stress. Such effects do not amount to injury; it is for this reason that they fall outside the matters that need to be considered when the proportionality rule is being applied.

${ }_{4}$ Collateral damage can include the effects that are the direct consequence of an attack, including a nuclear attack, as well as those that are somewhat indirect. The important factors are whether the particular collateral damage is expected to occur and whether it will be caused by the attack. If the indirect effects should be expected by the persons planning, approving or executing the attack, they should be included in the collateral damage when a decision is being made as to whether the prospective attack breaches the Rule. Consider, for example, a planned conventional strike against a nuclear weapon storage facility. When applying the present Rule, planners, commanders and those undertaking the attack must consider all the expected consequences of the attack, including the civilians that will be killed or injured and the civilian objects that will be destroyed or damaged as a result of the blast and fragmentation released by the explosion. They must also consider the collateral damage that is expected to be caused by the release and subsequent spread of nuclear contamination as a result of the attack. The vital element here is the

70 Note the definition of the corresponding war crime in Rome Statute, Article 8(2)(b)(iv). 
requirement carefully to assess what collateral damage, whether direct or indirect, should be expected.

5 The notion of excessiveness that is central to the rule is not defined. It is not a matter of counting civilian casualties and comparing them to the number of enemy combatants that have been put out of action'. ${ }^{71}$ Indeed, there is no commonly accepted scale for the measurement of military advantage. It is a somewhat subjective notion, best viewed through the eyes of the person who is making the targeting decision. Equally, measuring expected civilian casualties and damage to civilian objects is no straightforward matter. Even if scales could be devised for military advantage and for collateral damage, those scales would not have similar units of measurement, which further complicates the application of the Rule. What is required is that the decision-maker must consider carefully what the military benefit is that is anticipated from the proposed attack and must assess the degree of death or injury to civilians and damage to civilian objects that can be expected to arise from the attack. Acting in good faith, the attacker must then decide whether a reasonable decision-maker, knowing what he or she knows, would proceed with the attack. If, after suitably careful thought, the decision-maker determines that the answer is in the affirmative, he or she should proceed with the attack. In the context of nuclear operations, it may well be the case that the military advantage that is anticipated as accruing from such an attack will be very large. The notion of 'proportionality' implicitly recognises that even if the incidental collateral damage that is expected is considerable, it may not necessarily be excessive in relation to the size of the anticipated military advantage. It is important to remember that the proportionality rule is only breached if the expected collateral damage is excessive in relation to the concrete and direct military advantage that is anticipated as accruing from the attack. Accordingly, if a reasonably well-informed person in the circumstances of the actual decision-maker, making reasonable use of the information available to him or her, could have expected excessive civilian casualties or damage to result from the attack, whether nuclear or conventional, but nevertheless proceeds with the attack, that may well amount to a war crime. ${ }^{72}$ It is widely accepted that considerable/extensive expected collateral damage could prove not to be excessive if the anticipated military advantage is sufficiently great. Likewise, even rather small collateral damage may be excessive in relation to a modest degree of military advantage. ${ }^{73}$

${ }^{71}$ AMW Manual, Commentary accompanying Rule 14.

72 Consider Galić Trial Chamber Judgment, para. 58.

73 Tallinn Manual 2.o, Commentary accompanying Rule 113, para. 8. 
6 The words 'concrete and direct' show that speculation and guesswork have no place in the proportionality assessment. The anticipated military advantage must be real, and the decision-maker must be able to articulate what it consists of. Some authorities suggest that the military advantage must also, in many cases, be quantifiable. ${ }^{74}$ The present authors agree with the AMW Manual that, while this will often be the case, it will not necessarily be so; what matters is that it be identifiable and capable of articulation. The Commentary to API states that "the expression "concrete and direct" was intended to show that the advantage concerned should be substantial and relatively close, and that advantages which are hardly perceptible and those which would only appear in the long term should be disregarded'. ${ }^{75}$ The treaty language does not specify whether the time period within which the advantage must be realised must or can be short, medium or long. However, the greater the time gap, the more likely it is that the advantage is either speculative or indirect, and thus should be excluded from consideration. The present authors reject arguments to the effect that the use of nuclear weapons to bring a conflict to an early end is justifiable on that ground alone, notwithstanding that, by reference to the principle of distinction and its subsidiary rules, the nuclear operation in question would be regarded as unlawful.

7 The concrete and direct military advantage to be considered when applying the proportionality test is generally accepted as being what is expected to stem from the attack considered as a whole and not from isolated or particular parts of it. ${ }^{76}$ It is imaginable that in the future very limited yield nuclear weapons could be used as part of a broader attack (e.g. involving a major advance, an amphibious landing or some attack of similar breadth and magnitude). The proportionality test should be considered by reference to the broader attack as a whole, not by reference only to the part of it that involved the use of the limited yield nuclear weapon. It seems unlikely that nuclear weapons of any size will be used to divert attention from the focus of a major attack. If, say, a conventional weapon were to be used to divert the enemy's attention in that way, it will be the military advantage to be derived from the

UK Manual, para. 5.33.3; Canadian Manual, para. 415; AMW Manual, Commentary accompanying Rule 14, para. 9.

75 API Commentary, para. 2209.

$7^{6}$ See UK statement on ratification of API on 29 January 1998, para (i); similar statements made by Australia, Germany, Italy and the Netherlands; UK Manual, para. 5.33.5; Canadian Manual, para. 415; German Manual, para. 444; ICRC Customary Law Study, Commentary accompanying Rule 14; NIAC Manual, Commentary accompanying para. 2.1.1.4. Note also the use of the word 'overall' in Rome Statute, Article 8(2)(b)(iv). 
overall major attack that should be considered when applying the proportionality rule.

8 The words 'expected' and 'anticipated' make it clear that this Rule is concerned with decisions that are made before the attack takes place. This reinforces the point, made earlier, that those who plan, approve or execute such attacks must make decisions that are reasonable by reference to all apparently reliable and reasonably available information. ${ }^{77}$ So, when any attack including a prospective nuclear attack is being considered, absolute certainty as to the prospective military advantage is not required, but a mere possibility of a military advantage will be insufficient even to be considered in the proportionality evaluation. While in conventional attacks the terms 'expected' and 'anticipated' give a reasonable scope for the exercise of individual judgment, ${ }^{78}$ something close to certainty as to the military advantage will, in practice, be required in the case of a nuclear attack.

9 The relationship between this Rule and the Rules on precautions in attack is important. The focus of the present Rule is to prohibit attacks that breach it. The precautions Rules, by contrast, prescribe steps that attackers and those in control of territory liable to be attacked must take in order to seek to ensure that the principle of distinction, the prohibition of indiscriminate attacks and the rules on special and specific protection from attack are complied with.

\section{Nuclear Targeting: Precautions}

How exactly the rules on precautions in attack apply in relation to nuclear attacks is a matter of no small controversy. There are those who argue that the constant care principle is the only rule to apply in such circumstances. Others suggest that most of the precautions set forth in Article 57 of API apply when nuclear weapons are to be used. By way of an additional complication, States that are parties to API but that made nuclear statements when ratifying that treaty such as the statement referred to in footnote 67 above might argue that the rules in Article 57(2) and (3) of API constitute sophisticated developments

77 Galić Trial Chamber Judgment, paras. 58-60; United States of America v. William List et al. (The Hostages Trial), United States Military Tribunal in Nuremberg, Case 47 (8 July 194719 February 1948) Law Reports of Trials of War Criminals, vol. VIII (1949) 34, 69; AMW Manual, Commentary to Rule 14; UK Manual, para. 5.20.4; Canadian Manual, para. 418; NIAC Manual, Commentary accompanying para. 2.1.1.4. Note also statement (c) made by the United Kingdom on ratification of API on 28 January 1998; some other States made statements in similar but not necessarily identical form.

$7^{8}$ API Commentary, para. 2210. 
of the obligation to take precautions in attack and that, as such, they constitute new rules introduced by API to which the nuclear statement applies. This would mean that, for such States, Article 57(2) and (3) would not apply to the use of nuclear weapons - though, arguably, would continue to apply to conventional attacks against nuclear weapon facilities.

The present authors take the position that, for all States, the constant care principle applies both to nuclear attacks and to conventional attacks on nuclear weapons. They also consider that, to the extent that the additional Article 57 rules articulate precautions that a nuclear attacker must of necessity take if constant care is in practice to be complied with, those additional rules therefore apply to all States if nuclear weapons are to be used or are to be made the object of an attack. This is the position that is reflected in the following Rules.

\section{Constant Care}

\section{Rule 39}

During nuclear operations constant care shall be taken to spare the civilian population, individual civilians and civilian objects.

1 The Rule is based on Article 57(1) of API. It reflects a principle of customary law that applies in both international and non-international armed conflicts. The Rule applies to nuclear operations. While in most - probably all circumstances the use of a nuclear weapon will amount to a devastating attack, Article $57(1)$ refers to 'operations'; it is thought right to reflect that notion, wider as it is than attacks, in the Rule.

2 The Rule requires those undertaking nuclear operations to consider the injurious and/or damaging effects of such operations on civilians and civilian objects. ${ }^{79}$ The Rule should be interpreted as supplementing the distinction principle set forth in Rule 30 , the indiscriminate attacks rule set forth in Rule 37 and the proportionality rule set forth in Rule 38. The obligation is for all those involved in the conduct of nuclear operations to take constant care commensurate with their respective roles and their involvement in the operation. "The degree and nature of the responsibility of each individual depends, inter alia, on the nature and extent of that individual's role, on the rank of the individual, on the operational relationships between the persons involved, and on the information available to the particular individual at a specific time. ${ }^{, 80}$ 
The constant care duty is therefore subject to this practicability caveat, which may be particularly relevant in the case of a commander of a naval submarine or indeed the pilot of a nuclear-armed aircraft, who may be in no position to undertake the precautionary measures prescribed by Article 57 of API and who may accordingly be relying on the precautionary steps taken by others in the operational planning process. Nevertheless, all persons involved in nuclear operations are legally required at all times to be cognisant of the effects of their operations on the civilian population, individual civilians and on civilian objects. They must, to the extent that they are able, always seek to avoid any such effects that are unnecessary and adverse. ${ }^{81}$

3 The word 'constant' indicates that there is no time during the preparation and conduct of nuclear operations when care can be dispensed with. The duty to take care applies throughout such operations and all those involved must discharge it. ${ }^{82}$ There is no time during the planning and execution processes when those involved are permitted to ignore the effects of their nuclear operations on the civilian population and/or on civilian objects. ${ }^{83}$ The practical compliance with this Rule will inevitably presuppose the application of the further precautionary measures referred to in Rules $40-46$.

\section{Verification of Target Status}

\section{Rule 40}

Those who plan or decide upon a nuclear attack shall do everything feasible to verify that the objective to be attacked is neither civilians nor civilian objects and is not subject to special protection.

1 This Rule is based on Article 57(2)(a)(i) of API. It applies in both international and non-international armed conflict and has customary law status. While Article 57(2)(a)(i) is arguably a new rule introduced by API, and therefore is a rule to which the nuclear statements made by NATO States when ratifying the treaty would apply, the Rule also describes action that an attacker must of necessity undertake if the constant care principle set forth in Rule 39 is to be complied with. The present authors are therefore satisfied that this Rule applies to all States in respect of attacks using nuclear weapons. Unlike Rule 39, which applies to nuclear operations, this Rule applies to nuclear attacks as defined in Rule 29.

Tallinn Manual 2.0, Commentary accompanying Rule 114, para. 5.

83 AMW Manual, Commentary accompanying Rule 30. 
2 It is important to be clear as to the persons towards whom this Rule is directed. The planning process will necessarily include decision-making about certain features of the intended attack. The notion of 'those who plan' may therefore include more individuals than may be initially apparent. Planners will comprise all persons who are involved in the targeting process up to the point when the final decision to attack is made, including those who make decisions as to the preferred exact target point; as to the preferred yield of the device that is to be used; as to compliance with distinction, discrimination and proportionality; as to the chosen manner of delivery (where there is a choice); as to the route to be followed; as to how precautions in attack will be implemented; as to battle damage evaluation; and as to numerous other matters. Essentially, they will be all the persons charged with drawing up the operational orders and instructions that will govern the conduct of the attack.

3 'Those who decide upon a nuclear attack' will be the persons whose task it is to decide that the attack shall be undertaken. In the case of nuclear attack, such decisions will generally be taken at the highest level of government and will be transmitted to the armed forces for execution. Senior armed forces commanders may be privy to the probably strategic basis for the decision to undertake a nuclear attack and may also become aware of information that suggests that the object of the attack is no longer a lawful target. In such circumstances, while the senior commander may not have decided upon the nuclear attack, he or she must take appropriate steps, such as drawing the further information to the attention of the original decision-maker in a timely way.

4 A person who executes a nuclear attack (e.g. the commander of a nuclear-armed submarine or the pilot of a bomber aircraft) may have no capability to determine the nature of the target that is to be engaged and may, equally, have no practical possibility of determining whether distinction, discrimination, proportionality and precautions principles and rules have been complied with. Ignorant as that commander or pilot may well be as to the nature and circumstances of the target, the extent of his or her role will be to fire the missile containing the nuclear weapon against predetermined co-ordinates, the geographical significance of which may be unknown to him or her. The chances are that the submarine commander or the pilot will not have available to him or her the information on which the planning of the attack and the high-level decision to execute it were based. Moreover, if, as is likely, a nuclear attack would involve the employment of stand-off capabilities, the submarine commander or bomber pilot is likely to be in no position to conduct real-time observation 
of the target area with a view to confirming or negating the information that led to the conclusion that the object or persons in question constitute a lawful target. It follows from this that the question for the submarine commander or bomber pilot is whether he or she has any information leading him or her to conclude that the decision to direct the nuclear attack at the chosen target on the specified occasion is apparently wrong. If the submarine commander or bomber pilot has little or no information available to him or her as to the status of the target or of the target area, he or she will have no basis for questioning the superior instruction to undertake the nuclear attack. The responsibility for that decision and for the ensuing attack will rest with the authority that authorised the attack. ${ }^{84}$

5 The word 'feasible' has been widely interpreted as an obligation to do that which is practicable or practically possible, taking into account all circumstances ruling at the time, including humanitarian and military considerations. ${ }^{85}$ Feasible action to verify the status of the target as a lawful target will necessarily involve the obtaining and consideration of all reasonably available information about the target. If information is available, it must be assessed to determine its reliability and it must then be considered in conjunction with the other apparently reliable and available information. The purpose of the process is to determine whether the available information, considered as a whole, confirms that the object of the attack consists of a military objective, combatants or directly participating civilians. If it is practicable to obtain a particular item of apparently relevant information, it must be obtained and considered. If it is not practicable to obtain that item, the obligation does not apply.

6 As to the standard applicable in naval and air warfare, see Rule 42.

7 If, on the basis of the reasonably available information, it is not possible to determine whether the object of the suggested attack is or is not a lawful target, the suggested attack cannot proceed. If the reasonably available information clearly shows, however, that some smaller object or group of persons is a lawful target, the Rule will have been satisfied in respect of that smaller target, but a more limited, conventional attack will almost certainly be called for because of the reduced scope of the persons or object(s) that can lawfully be made the object of the attack.

84 AMW Manual, Commentary accompanying Rule 32a, para. 4.

85 See statement (b) made by the United Kingdom on ratification of API on 28 January 1998; UK Manual, para. 5.32; Canadian Manual, A-4; AMW Manual, Rule 1q; ICRC Customary Law Study, Commentary accompanying Rule 15. 


\title{
Choice of Means or Methods
}

\begin{abstract}
Rule 41
Those who plan or decide upon an attack, including a nuclear attack, shall take all feasible precautions in the choice of means and methods of attack with a view to avoiding, and in any event to minimising, incidental loss of civilian life, injury to civilians and damage to civilian objects.
\end{abstract}

1 This Rule is based on Article 57(2)(a)(ii) of API. It reflects action by an attacker that is in practice required if the principles of distinction and discrimination are properly to be complied with and is an essential manifestation of the constant care rule set forth in Rule 39. It cannot be consistent with the generally accepted obligation to take constant care to spare the civilian population and civilian objects for parties to an armed conflict to undertake a particular nuclear attack knowing that, by choosing an alternative weapon or method of undertaking the attack, the military purpose could be achieved with reduced collateral damage.

2 The Rule reflects customary international law and applies in both international and non-international armed conflicts. As to the meaning of 'those who plan', see paragraph 2 of the Commentary on Rule 40. As to the meaning of 'those who decide upon a nuclear attack', see paragraph 3 of the Commentary accompanying Rule 40. As to 'feasible' see paragraph 5 of the Commentary accompanying Rule 40. As to the meaning of 'means' and 'methods', see Rule 69.

3 It is important to understand the relationship between the present Rule and the proportionality rule, set forth at Rule 38 above and operationally applied in Rule 43 below. Even if a method of attack has been chosen that complies with the proportionality rule, the present Rule requires that an alternative method be chosen if it will further reduce collateral damage. All available options for achieving the desired military advantage must be considered. So, imagine a situation in which an attack on a military port facility using a nuclear weapon is being contemplated. In the hypothetical example, the port facility that is the focus of the intended attack could be eliminated equally efficiently and reliably by means of an air attack using a number of 2,ooo lb laser-guided bombs. The nuclear option would risk the release of nuclear particles that could be expected to cause large numbers of casualties among the civilian population living near the port. The obligation to exercise constant care to spare the civilian population requires that the attack option be chosen that minimises loss of civilian life and injury to civilians. However, and importantly, this Rule does not require an attacker to select an alternative method of attack that yields less military advantage. 
4 The Rule addresses the avoidance or minimisation of civilian injury, death and/or damage which is incidental to the securing of the anticipated military advantage. Accordingly, civilian injury, death or damage that would be the direct or indirect consequence of an attack must be avoided or minimised to the extent it is practically possible to do so. ${ }^{86}$ This means that weapons must be chosen and ways of using them must be selected with a view to avoiding where possible, and at any event to minimising, collateral damage.

\section{Specifics of Naval and Air Operations}

\section{Rule 42}

In the conduct of naval and air operations, the parties to the conflict shall take all reasonable precautions to avoid losses of civilian lives and damage to civilian objects.

1 This Rule is based on Article 57(4) of API, which, according to Article 49(3) of API, applies only to 'air or sea warfare which may affect the civilian population, individual civilians or civilian objects on land'. In the conduct of naval and air operations directed against targets on land, the obligations under Rules 39-46 continue to apply.

2 Arguably, neither the standard of 'feasibility' nor the standard of 'reasonableness' applies to naval and air operations that are not directed against targets on land and that are not able to affect protected persons and objects on land. In other words, the Rules on precautions in the present Section would be inapplicable to sea-to-sea, air-to air, air-to-sea and sea-to-air operations that are not expected to affect individuals or objects on land. Consider a nuclear or conventional attack against a nuclear-propelled aircraft carrier in the high seas. At least the States that are parties to API and have not made a nuclear statement will therefore have to decide which precautionary standard they are to apply.

3 However, in the view of the present authors, the possible interpretations of the relevant provisions in API are without prejudice to the corresponding obligations under customary international law. Arguably, there is no substantial difference between 'feasible' and 'reasonable' precautions, ${ }^{87}$ so the same precautionary standards apply to any sea and air operations, including nuclear operations. $^{88}$

\footnotetext{
See US DoD Law of War Manual, para. 5.11.

US DoD Law of War Manual, para. 5.3.3.1.

88 San Remo Manual, para. 46; AMW Manual, para. 32 (both recognising the standard of 'feasible').
} 
4 The Rule is of considerable relevance for naval and air operations in the high seas or in international airspace involving the use of nuclear weapons against enemy targets or consisting of conventional attacks against nuclearpropelled or nuclear-carrying enemy platforms. In both situations, the parties to the conflict are obliged to take all reasonable precautions to avoid harmful effects on innocent shipping and, to the extent it is protected under customary international law, on the marine environment.

\section{Precautions in Implementing the Proportionality Rule}

\section{Rule 43}

Those who plan or decide upon attacks, including nuclear attacks, shall refrain from deciding to launch any attack that may be expected to cause incidental loss of civilian life, injury to civilians or damage to civilian objects, or a combination thereof, which would be excessive in relation to the concrete and direct military advantage anticipated.

1 This Rule is based on Article 57(2)(a)(iii) of API. It reflects action by an attacker that is in practice required if the principles of distinction and discrimination are to be complied with properly and is an essential manifestation of the constant care rule set forth in Rule 39. It cannot be consistent with the generally accepted obligation to take constant care to spare the civilian ${ }^{89}$ population, civilians and civilian objects for parties to an armed conflict to simply proceed with an attack knowing that it can be expected to cause collateral damage that outstrips the military advantage that the attack, whether nuclear or conventional, is anticipated to yield. The Rule reflects customary law and applies in both international and non-international armed conflicts.

2 The proportionality rule is reflected in Rule 38 above. The present Rule reflects the obligation of planners and decision-makers to apply the proportionality rule when deciding whether a conventional or nuclear attack shall be undertaken.

3 A person who executes a nuclear attack (e.g. the commander of a nucleararmed submarine or the pilot of a bomber aircraft) may have no capability to determine the status of the target or of the target area nor whether distinction, discrimination, proportionality and precautions principles and rules have been complied with. Ignorant as that commander or pilot may well be as to what is going on in the target area, the extent of his or her role will be to fire the

89 Canadian Manual, para. 417; German Manual, para. 457; AMW Manual, Rule 32c and chapeau to Section G; ICRC Customary Law Study, Rule 18. 
missile containing the nuclear weapon against predetermined co-ordinates without knowing what is in fact going on in that location. The chances are that the submarine commander or the bomber pilot will not have available to him or her the information on which the planning of the attack and the high-level decision to execute it were based.

Moreover, if, as is likely, a nuclear attack would involve the employment of stand-off capabilities, the submarine commander or bomber pilot is likely to be in no position to conduct real-time observation of the target area with a view to confirming or negating the information that led to the conclusion that the nuclear attack would comply with the proportionality rule. It follows from this that the question for the submarine commander or bomber pilot is whether he or she has any information leading him or her to conclude that the decision to undertake that nuclear attack is clearly wrong. If the submarine commander or bomber pilot has little or no information available to him or her as to the status of the target or of the target area, he or she will have no basis for questioning the superior instruction to undertake the nuclear attack. The responsibility for that decision and for the attack will rest with the authority that authorised the attack. ${ }^{90}$

\section{Choice of Targets of Nuclear Attack}

\section{Rule 44}

This Rule applies only to States that are parties to API. When a choice is possible between several military objectives for obtaining a similar military advantage, the objective to be selected for a nuclear attack shall be that the attack on which may be expected to cause the least danger to civilian lives and to civilian objects.

1 The Rule is based on Article 57(3) of API. The authors note that the United States considers this Rule not to have customary law status ${ }^{91}$ and they share that view in its potential application to nuclear attacks. Indeed, it is questionable whether this Rule is a necessary element of the constant care principle. Arguably, it is a new rule that was introduced by API, so, for the States which, when ratifying the treaty, made statements excluding the application of such new rules to nuclear weapons, this Rule will indeed not apply in relation to nuclear attacks. The Rule will, however, apply to all States that are parties to

$9 \circ$ AMW Manual, Commentary accompanying Rule 32a, para. 4.

$9^{1}$ US DoD Law of War Manual, para. 5.11.5. 
API and that did not make such a statement excluding or materially limiting the application of Article 57(3).

2 The Rule does not limit its application to planners or decision-makers. It must therefore be complied with by all those who are involved in selecting targets for nuclear attack, in approving such targets and in actually conducting nuclear attacks..$^{92}$ The notion of danger to civilian lives and objects suggests that civilians must be at risk of injury or death and/or that civilian objects must be at risk of destruction or damage. Any of these four dangers will be sufficient for the Rule to apply.

3 The Rule applies only if a choice is possible - that is, if attacking the alternative military objective(s) is militarily feasible and offers a reasonable expectation of success. Moreover, the alternative target(s) must offer a similar military advantage. When the required comparison is made, the alternative attacks must be considered as a whole, not isolated elements of them. It is in practice unlikely that alternative targets will be available the nuclear attack of which may be expected to offer similar military utility. The more likely situation will be a choice between a large-scale nuclear attack of a military facility such as a base and, as the alternative, a smaller-scale, conventional attack against a significantly more limited target. If the military purpose can be successfully achieved by means of a smaller-scale attack that poses less danger to civilians and civilian objects, this is the option that should be adopted. 93

\section{Cancellation or Suspension of Nuclear Attacks}

\section{Rule 45}

An attack, including a nuclear attack, shall be cancelled or suspended if it becomes apparent that the objective of the attack is not a military one or is subject to special protection or that the attack may be expected to cause incidental loss of civilian life, injury to civilians or damage to civilian objects, or a combination thereof, which would be excessive in relation to the concrete and direct military advantage anticipated.

1 This Rule reflects Article 57(2)(b) of API. It is a necessary manifestation of the constant care principle reflected in Rule 39 and therefore applies as a rule of customary law to the conduct of nuclear attacks. To proceed with a nuclear attack when it has become apparent that the object of the attack is no longer

92 Tallinn Manual 2.0, Commentary accompanying Rule 118, para. 3.

93 Consider AMW Manual, Commentary accompanying Rule 33, paras. 3-6; Tallinn Manual 2.0, Commentary accompanying Rule 118, paras. 5-7. 
a lawful target or that the attack will cause excessive collateral damage by reference to the anticipated military advantage would be clearly inconsistent with the obligation to take constant care to spare civilians and civilian objects. The Rule is customary in nature and applies in international and noninternational armed conflicts.

2 It should be noted that this Rule is not subject to the feasibility criterion. The obligation to cancel or suspend is therefore an absolute requirement if the circumstances set forth in the Rule apply. A previous determination may have been made that, for example, an object is a military objective and that attacking it would comply with the proportionality rule. If, however, further information becomes available showing that, for example, the object is no longer being used for military purposes or that civilians are now located closer to the object and in larger numbers, the Rule requires the attacker either to cancel the attack or at least to suspend it until the additional information can be considered to decide whether the object remains a military objective and whether, under the changed circumstances, the attack still complies with the proportionality rule.

3 Consider, for example, a compound that is known to contain some nuclear material and which a party to the armed conflict has decided to attack. The collateral damage estimate and the targeting decision are made on a Monday, with a view to the attack actually taking place forty-eight hours later on the Wednesday. During the intervening period, on the Tuesday morning, a group of civilian internally displaced persons is seen to have taken up residence near the perimeter fence of the military facility. The decision to attack should at least be suspended for long enough to determine what the revised estimate as to civilian casualties amounts to and to assess whether the expected increased injuries and deaths among the civilians would be excessive in relation to the military advantage that a successful attack of the object can be anticipated to yield. It may be possible to make that revised assessment rapidly, but the assessment must be a proper one, based on an appropriate consideration of all available information, including that which has become available recently.

4 The circumstances, and the capabilities of the particular weapon system, will determine whether at any particular moment it is practically possible to cancel or suspend an attack. If the missile has not yet been launched and if there is continuous communication between the authority that directed the launch and the platform tasked with carrying it out, the communication rescinding that order should be sent as urgently as possible, with a requirement that the recipient acknowledge receipt of the rescinding instruction immediately. A considerably more difficult situation arises if there is no such 
continuous communication. While very great caution is always required before any instruction to launch a nuclear weapon is sent, if there is no continuous communication with the launch platform, that caution should be extreme.

5 If the missile has already been launched and if the attack cannot be aborted, it follows that cancellation or suspension will not be possible following launch and that the Rule will therefore cease to apply after launch has taken place. If, however, during the period after launch and before detonation the weapon support systems can enable the diversion of the missile from the target and the disarming of the missile, such action should be taken if it becomes clear that either of the circumstances mentioned in the Rule applies. While there is no rule of law requiring that such missiles be controlled by an operator and that they be capable of diversion and/or disarming, such a capability would seem to the authors to be highly desirable, as it would enable a potentially disastrous attack to be avoided or at least to be mitigated. Consider, for example, a situation in which an operator of a nuclear-armed missile notices that the munition is flying towards the wrong co-ordinates. Without a mission abort mechanism, the operator would be unable to prevent the wrongful attack of, say, a civilian object. If the weapon were to have such a capability and depending on the exact nature of that capability, the person at the controls would be able to divert the missile from its erroneous target and/or at least to disarm the missile. While the constant care principle probably does not actually require the fitting of such a monitoring and aborting/diverting facility, it would certainly be desirable for such a capability to be fitted.

\section{Warnings}

\section{Rule 46}

Effective advance warning shall be given of an attack, including a nuclear attack, that may affect the civilian population, unless circumstances do not permit.

1 This Rule is based on Article 26 of the Hague Regulations and Article 57(2)(c) of API. It reflects customary international law and applies in international armed conflicts. ${ }^{94}$ The position is less clear in relation to non-international armed conflicts. With regard to cultural property, see Rule 62 below. The Rule

94 US DoD Law of War Manual, para. 5.11.1; UK Manual, para. 5.32.8; Canadian Manual, para. 420; German Manual, paras. 447, 453, 457; AMW Manual, Rule 37 and accompanying Commentary; ICRC Customary Law Study, Rule 20. 
applies only if the civilian population is exposed to the risk of death or injury, as will often be the case with a nuclear attack and with a conventional attack on a nuclear weapon capability. It does not apply if - perhaps unusually - the danger is limited to damage to or destruction of civilian objects. It is generally accepted that the Rule is not engaged if the effect on the civilian population will consist of mere inconvenience, annoyance, fear or stress. ${ }^{95}$

2 To be effective, the person or persons to be warned must receive the warning in time to be able to act accordingly. ${ }^{6}$ If the warning is to be effective, it must be understood by the persons to whom it is directed. If it consists of text, this must be in a language that the recipients understand. Alternatively, it may consist of clear, intelligible drawings, or may take the form of audible communications. It may be communicated via leaflets dropped from an aircraft; messages broadcast via broadcasting stations used by the relevant population; emails, social media or other means; or indeed any combination of these methods. There is no obligation to use the most effective or individual method of communication that may be available. Ultimately, the warning will be effective - and, thus, comply with the Rule - if it generally comes to the attention of the population intended to receive it and if they understand the action they should take.

3 Certain operational contexts may preclude the giving of warnings. Thus, if giving a warning will prejudice an attack, the circumstances do not permit the giving of a warning and no warning is required. ${ }^{97}$ Depending on the location and other circumstances surrounding the attack, a strategic nuclear attack is likely to affect the civilian population in the sense of the present Rule and is unlikely to be prejudiced by the giving of a warning. Accordingly, in such circumstances a warning will usually be required. If, however, surprise is an essential aspect of, say, a successful conventional attack on a facility where nuclear weapons are being held (because the giving of a warning would enable the enemy to take defensive measures that would frustrate or preclude the attack), this would exclude the application of the Rule. Such defensive measures might include the use of combat aircraft, ground-based air defence, the employment of cyber techniques or, indeed, other measures such as the concealment of the weapons that are to be targeted. Equally, if the giving of a warning would prompt the enemy to pre-empt the situation by undertaking a similar attack itself, or if force protection considerations demand that no

AMW Manual, Commentary accompanying Rule 37.

UK Manual, para. 5.32.8.

US DoD Manual, para. 5.11.1.3; UK Manual, para. 5.32.8; Canadian Manual, para. 420; AMW

Manual, Commentary accompanying Rule 37; API Commentary, para. 2223. 
warning be given, these may also justify a decision not to give a warning. It should, however, be emphasised that such factors will not necessarily preclude the giving of a warning, and if a warning will not adversely affect the attack arrangements, a warning should be given.

4 An aspect that should be taken into account when deciding whether to issue a warning is that the warning may be rather general in nature, referring to attacks against a type of target but not specifying the date, time or precise nature of the particular attack.

5 Alternatively, the giving of a warning may support the strategic purpose that prompts consideration of a nuclear attack. The warning may combine compliance with the present Rule with an attempt to persuade the enemy leadership to take a preferred course of action, such as attending peace talks. There is, however, an important difference in purpose between threatening a nuclear attack and giving a warning for the purposes of the present Rule. Such a threat is essentially coercive in nature, whereas the purpose of the warning under the present Rule is essentially protective. Both, however, will send a powerful message to the adversary.

6 A warning under the present Rule may be issued as a ruse (i.e. with the purpose of misleading the adverse party). ${ }^{9}$ Such action would not be unlawful, 99 but may be militarily counterproductive if the coercive effect of future threats is thereby eroded.

\section{Precautions against the Effects of Attacks}

\section{Rule 47}

The Parties to the conflict shall, to the maximum extent feasible, take necessary precautions to protect the civilian population, individual civilians and civilian objects under their control against the dangers resulting from nuclear attacks.

1 The basis for this Rule is Article 58(c) of API, but it also derives some support from Article $27(2)$ of the Hague Regulations. ${ }^{100}$ While Article 58(c) refers to protection from military operations, the historical provisions - to the extent that they are relevant - suggest that the customary provision applies to

Consider also Draft Hague Rules of Aerial Warfare, Articles 25(2), 26(4). These early provisions do not entirely reflect the contents of the present Rule, but indicate early thinking of that kind. 
protection against the effects of attacks. ${ }^{101}$ The Rule has customary international law status and applies during international armed conflicts. During non-international armed conflicts, the obligation of the government forces to take such precautions will derive from the sovereign duty of the State to take appropriate steps to ensure the security of the population.

2 As the text of the present Rule makes clear, its focus is on the duty of a party to the conflict that controls territory to take precautions to protect the population and civilian objects in that territory. These precautions are sometimes referred to as 'passive' or 'defender's' precautions. Both labels are misleading. The required precautions may well involve positive action, not just passivity; and a party that is in control of territory may have secured that control in the course of an invasion or military advance which is anything but defensive in nature. It is better to regard the precautions required by the present Rule as those which are needed to seek to ensure, as far as possible, the safety of the population and of civilian objects from the dangers associated with attacks, including nuclear attacks. It will be for each party to the conflict to determine which precautions are necessary for this purpose.

Consideration will need to be given, inter alia, to the following:

removing the civilian population, individual civilians and civilian objects from the vicinity of military objectives; ${ }^{102}$

avoiding locating military objectives near populated areas; ${ }^{103}$

constructing suitable shelters for the civilian population to protect them against attacks, including nuclear attacks;

issuing guidance to the civilian population on what to do in the event of nuclear attack;

developing a warning system to warn of impending nuclear attack; promulgating the details and significance of the various warning signals; stockpiling food and water for use by the civilian population in the event of nuclear attack;

issuing of protective clothing, masks and other equipment necessary to protect against the effects of nuclear attack;

ensuring that medical facilities are available to deal with the likely numbers of patients affected by nuclear contamination;

101 Note that the title of Article 58 refers to 'Precautions against the effects of attacks'.

102 AMW Manual, Rule 43; ICRC Customary Law Study, Rule 24; Tallinn Manual 2.0, Commentary accompanying Rule 121, para. 10.

103 AMW Manual, Rule 42; ICRC Customary Law Study, Rule 23; Tallinn Manual 2.0, Commentary accompanying Rule 121, para. 11. 
establishing, maintaining and equipping an appropriately trained civil defence force; and

establishing, maintaining and equipping efficient civilian emergency services.

These are, of course, only examples of the kinds of precautionary measure that a party to the armed conflict that is in control of territory will have to consider. Some such measures may require action before the commencement of hostilities. Other such measures may more sensibly be taken a little later. Not every armed conflict involving a nuclear power will give rise to the use of nuclear weapons. Indeed - fortunately - history suggests that most will not. What is required by this Rule is that the governmental authorities of a party to the conflict assess the precautionary action that is required to ensure the security and safety of the civilian population and then take that required action.

3 This Rule does not re-state explicitly Article 58(a) and (b) of API, because removing the civilian population from the vicinity of military objectives and avoiding locating military objectives near populated areas are, as the previous paragraph of this Commentary has demonstrated, subsumed within the overall obligation set forth in the Rule. Nevertheless, in fulfilling its duties under this Rule, a State in control of territory must take necessary and feasible action to keep the civilian population and military objectives apart from one another.

4 The Rule limits the action required through its use of the words 'to the maximum extent feasible'. The word 'feasible' is widely understood as referring to action that is practicable or practically possible taking into account all circumstances ruling at the time, including humanitarian and military considerations. ${ }^{104}$ The requirement is therefore to take all practically possible protective precautions, but there is no requirement to do that which is impractical. ${ }^{105}$ It will be recalled that any military use of an object that otherwise fulfils civilian purposes has the effect of rendering that object a military objective. It will often be impractical either to move such objects away from centres of population or to move the civilian population. However, if moving the object and moving the population are both impractical, other measures will still be required with a view to affording the civilian population as much protection as possible.

5 Whether a party to the conflict is in control of territory will be a question of fact. Territory under its control will include its national territory that it continues to control and any parts of the adverse party's territory that it has

104 See statement (b) made by the United Kingdom on ratification of API on 28 January 1998.

105 Consider API Commentary, para. 2245. 
invaded or over which it is otherwise exercising control. Territory the control of which is disputed (e.g. because ongoing hostilities are such that no party is in effective control) is not included within this Rule.

6 The dangers to which this Rule refers will comprise the risk that civilians will be killed or injured, that they will suffer sickness and that civilian objects will be damaged or destroyed. They will not include the risk of inconvenience or irritation, so a party to the conflict is not obliged to take precautions against such non-injurious consequences. While the Rule does not, arguably, require precautions to be taken where the anticipated consequences are limited to major disruption, in practice it seems likely that the consequences of a nuclear attack would in fact include injury or death of civilians and damage or destruction of civilian objects and major disruption. It would be sensible for parties to an armed conflict to include within the precautions they take under this Rule action aimed at mitigating such disruptive effects, although the Rule arguably does not explicitly require this.

7 The failure of a party to the conflict that is in control of territory to take necessary precautions in accordance with this Rule does not, per se, prohibit the other party to the conflict from conducting an attack, including a nuclear attack. ${ }^{106}$ Equally, the failure of the party in control of territory to take necessary precautions in accordance with this Rule does not excuse the other party to the conflict from the obligation to take all required precautions when undertaking attacks. That attacking party remains bound by the principles and rules on distinction, discrimination, proportionality and precautions. However, and depending on the particular circumstances of a specific attack, the failure of the party in control of territory to take necessary precautions in accordance with the present Rule may render the precautions taken by an attacker less effective - a factor that should be borne in mind when the attacker's conduct and its effects are being considered.

\section{Methods of Nuclear Warfare}

LOAC prohibits certain methods of warfare and imposes constraints on the employment of others. In the following Rules these prohibitions and restrictions will be stated and explained. The meaning of methods of nuclear warfare is given in Rule 69. 


\section{Perfidy}

\section{Rule 48}

In the conduct of nuclear operations, it is prohibited to kill or injure an adversary by resort to perfidy. Acts inviting the confidence of an adversary to lead him or her to believe that he or she is entitled to receive, or is obliged to accord, protection under the law of armed conflict with intent to betray that confidence constitute perfidy.

1 For the purposes of this book, perfidious killing or wounding and treacherous killing or wounding can be regarded as synonymous. Article 23 (b) of the Hague Regulations provides that it is especially forbidden ... (b) to kill or wound treacherously individuals belonging to the hostile nation or army'. Article $37(1)$ of API defines perfidy as '[a]cts inviting the confidence of an adversary to lead him to believe that he is entitled to, or is obliged to accord, protection under the rules of international law applicable in armed conflict, with intent to betray that confidence'. Killing or injuring a member of the adverse party to the conflict by resorting to perfidy is prohibited by customary law in both international and non-international armed conflicts. ${ }^{107}$

2 States that are parties to API are also prohibited by Article 37(1) of API from capturing an adversary by resort to perfidy. However, in the opinion of the present authors, this aspect of the treaty rule does not reflect customary law. ${ }^{108}$ The perfidy rule does not include causing damage or destruction by resort to perfidy. ${ }^{109}$ Similarly, a mere act of perfidy without adverse consequences for the enemy is not prohibited. It is the causing of death or injury (or capture) by this method that is prohibited.

3 The Rule is broken if the persons who are deceived are not the same persons as those who are killed or injured as a result of the deception, so long as those who are killed or injured were the intended casualties. However, there must be a direct causal link between the act of perfidy and the resulting death or injury. While it has been argued that an attempt to cause death or injury by resort to perfidy is also prohibited under this Rule, ${ }^{110}$ the authors consider that Article 23(b) of the Hague Regulations and Article 37(1) of API both clearly

107 Hague Regulations, Article 23(b); US DoD Law of War Manual, para. 5.21; UK Manual, paras. 5.9 15.12; Canadian Manual, paras 603, 706, 857; German Manual, para. 472; AMW Manual, Commentary accompanying Rule 111(a); NIAC Manual, para. 2.3.6; ICRC Customary Law Study, Rule 65; Rome Statute, Article 8(2)(b)(xi) and 8(2)(e)(ix). AMW Manual, Commentary accompanying Rule 111(a).

109 AMW Manual, Commentary accompanying Rule $111(\mathrm{a})$.

110 API Commentary, para. 1493. However, misuse of certain signs, indicia, uniforms, etc. is prohibited under LOAC, as reflected in the Rules below. 
require death or injury to have resulted from the perfidious act for the treaty rules to be broken.

3 The perfidious element consists in inviting the adversary's confidence that he or she is either entitled to receive protection under LOAC or obliged to give that protection to the party to the conflict that is practising the deception. Article 37(1) lists as examples of perfidy: feigning an intent to negotiate under a flag of truce or of a surrender; feigning an incapacitation by wounds or sickness; feigning civilian, non-combatant status; and feigning protected status by the use of signs, emblems or uniforms of the United Nations or of neutral or other States that are not parties to the conflict.

4 Consider, for example, a nuclear attack mission in which an aircraft bearing civilian markings and giving all the appearances of having civilian status is specially adapted to enable it to undertake a nuclear attack. Imagine that the attacking aircraft follows a routing routinely used by civilian commercial aircraft and that the adverse party's air traffic control authorities, believing the aircraft to be flying for normal civilian, commercial purposes and thus to be protected from attack, permits it to enter and fly through its national airspace in the usual way. The deaths and injuries resulting from the use of the nuclear weapon will have been caused by the perfidious act of feigning civilian status in order that the enemy considers itself obliged to grant the attacking aircraft protection, but with the intention of betraying the enemy's confidence. Accordingly, the present Rule will have been broken.

5 If a similar deception were to be employed, this time to enable a party to the conflict to attack its enemy's nuclear weapons, and if military personnel and/or civilians of the adverse party are killed or injured as a result of the attack, the Rule will again have been broken in the opinion of the present authors. However, consider the situation where, in the course of a mission to discuss a ceasefire, parlementaires take advantage of their presence in enemyheld territory to take action to disable or disrupt a critical part of the enemy's nuclear command and control system. If the effects of such an operation are limited to disabling or disrupting the system and if no death or injury of individuals belonging to the adverse party results, the present Rule will not have been broken. ${ }^{111}$ If a member of the armed forces fails to identify himself or herself as a combatant, this alone does not constitute perfidy. Likewise, if

11 The parlementaires will, however, have breached their status. Note also that a distinction must be drawn between perfidy and espionage. However, if a spying mission causes death or injury to an individual of the adverse party, this may also breach the present Rule if pretence as to protected status is involved. 
a military aircraft does not exhibit its military and national markings, that is not, per se, a perfidious act. It is the actual feigning of some other status protected under LOAC, with the intention thereby to deceive, that distinguishes perfidy. Likewise, using stealth technology in order to conceal the presence of an attack platform, such as a combat aircraft, is not perfidious. The deception that is being perpetrated concerns not protected status but rather the presence of the aircraft.

6 Lawful deception operations are addressed under Rule 49.

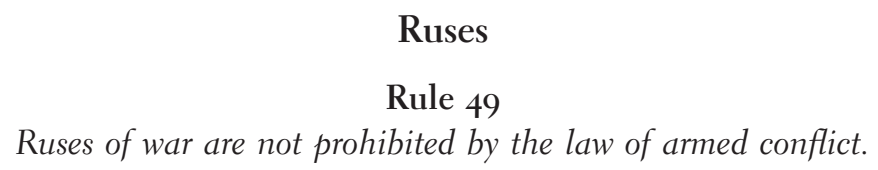

1 This Rule is based on Article 24 of the Hague Regulations and Article 37(2) of API. It reflects customary law and applies in both international and noninternational armed conflicts. ${ }^{112}$

2 Ruses are 'acts which are intended to mislead an adversary or to induce him to act recklessly but which infringe no rule of international law applicable in armed conflict and which are not perfidious because they do not invite the confidence of an adversary with respect to protection under the law' ${ }^{113}$

3 Examples of lawful ruses include:

using enemy codes, signals or passwords;

communicating false intelligence information with the intention that the enemy intercepts it and acts on it;

transmitting false orders purporting to have been issued by enemy commanders;

transmitting false information leading the adverse party to believe that nuclear weapons are being held in a false location;

sending communications that give a false impression as to the sending State's nuclear preparedness or intentions;

camouflaging installations at nuclear bases, camouflaging nuclear weapon delivery platforms or camouflaging other relevant systems; constructing decoy facilities to divert enemy attacks; and undertaking mock operations.

112 US DoD Law of War Manual, para. 5.25; UK Manual, paras. 5.17 and 15.12; German Manual, para. 471; AMW Manual, Commentary accompanying Rule 113; NIAC Manual, Commentary accompanying para. 2.3.6; ICRC Customary Law Study, Rule 57.

113 API, Article 37(2). 
4 Accordingly, giving the enemy a false impression as to what is happening so as to secure a military advantage is what lies at the core of lawful ruses. It must, however, be emphasised that, to be a lawful ruse, the deception must not involve any misrepresentation as to protected status under LOAC and the deception must itself not be unlawful (i.e. it must not breach any other LOAC rule). ${ }^{114}$ So, for example, if enemy codes and signals are used to confuse the enemy air defence forces and thus enable a nuclear attack to be undertaken unhindered, the misuse of the enemy codes and signals would be regarded as a lawful ruse of war. Likewise, consider the position where a State generates fake communications which appear to consist of instructions from the chief of its defence staff to the operational commander of its nuclear forces. The fake communications appear to instruct the subordinate commander to prepare to attack a specified target on a designated date and at a designated time by using a particular platform - say, a submarine - but the party to the conflict issuing the fake communications has no intention of undertaking such an attack, or of attacking the specified target. Such a ruse would not be unlawful, so long as the issue of protection under LOAC is not involved.

\section{Improper Use of Protective Indicators}

\section{Rule 50}

It is prohibited to make improper use of the protective emblems, signs or signals that are provided for in the law of armed conflict.

1 This is a rule of customary law that applies to international and noninternational armed conflicts. ${ }^{115}$

2 The protective emblems, insignia, etc. that are covered by this Rule include the Red Cross, Red Crescent and Red Crystal; ${ }^{116}$ the distinctive sign for civil defence; ${ }^{117}$ the distinctive emblem for cultural property; ${ }^{118}$

114 See AMW Manual, Commentary accompanying Rule 116(a).

115 Hague Regulations, Article 23(f); API, Article 38(1); APII, Article 12; APIII, Article 6(1); US DoD Law of War Manual, paras. 5.23, 5.24; UK Manual, para. 5.10; Canadian Manual, paras. 604, 605; German Manual, paras. 641, 932; AMW Manual, Rule 112(a) and (b); NIAC Manual, para. 2.3.4; ICRC Customary Law Study, Rules 58, 59, 61; Rome Statute, Article $8(2)(\mathrm{b})(\mathrm{vii})$.

116 GCI, Articles 38-44; GCII, Articles 41-5; APIII, Article 2(1); US DoD Law of War Manual, para. 5.24.2.

117 API, Article 66; UK Manual, para. 5.10 n. 41.

${ }_{118}$ Convention on the Protection of Cultural Property in the Event of Armed Conflict, The Hague, 14 May 1954 (Hague Cultural Property Convention), Articles 16, 17; US DoD Law of War Manual, para. 5.24.6; AMW Manual, Commentary accompanying Rule 112(a). 
the flag of truce; ${ }^{119}$ and electronic protective marks referred to in Annex 1 to API. ${ }^{120}$ The basis for these prohibitions lies in the likelihood that misuse of the indicators will make it more difficult for the persons or objects they are intended to protect to be identified, will cause the adverse party to doubt the credibility of such protective signs and thereby will expose protected persons and objects to greater danger. However, the improper use does not have to occasion death or injury for the Rule to be broken. Equally, if the misuse of the emblem, indices, etc. is used to cause damage but no death or injury results, the Rule will have been breached by virtue of the misuse, irrespective of the lack of resulting casualties.

3 LOAC includes additional indicators, such as the special sign indicating works and installations containing dangerous forces, as provided for in Article 56(7) of API and Article 16 of Annex I to the treaty. While the protection afforded to such objects by API does not have customary law status, the special sign is nevertheless provided for in LOAC and its improper use would constitute a breach of the present Rule.

$4 \mathrm{~A}$ use is improper if its function is not to identify the location, object or personnel that serve the protected purpose. The Rule is specific in referring to the false use of the protective emblems, signs or signals. While other action to feign protected status, but that does not involve the use of protective emblems, signs or signals, may breach other LOAC rules, it will not breach the present Rule.

5 Accordingly, if the protective emblem provided for in Article 56(7) of API - namely, a group of three bright orange circles placed on the same axis - were to be displayed on an installation where nuclear weapons are being stored, the present Rule would be breached. Equally, if a nuclear strike aircraft were to display Red Cross emblems, the Rule would also be breached. A third example would be to act on the knowledge that the enemy is planning a nuclear strike against a military installation by displaying the civil defence distinctive sign on it in an attempt to prevent the attack. In all of these circumstances, the Rule is broken by the misuse of the emblem, irrespective of the motive.

11 Hague Regulations, Article 23(f); API, Article 38(1); US DoD Law of War Manual, para. 5.24.7; AMW Manual, Commentary accompanying Rule 112; ICRC Customary Law Study, Rule 58.

120 API, Annex 1, Article 9. 


\title{
Unauthorised Use of United Nations Emblem
}

\author{
Rule $\mathbf{5 1}^{1}$ \\ It is prohibited to make use of the distinctive emblem of the United Nations \\ except as authorised by that organisation.
}

1 A rule of customary law prohibits the unauthorised use of the United Nations emblem in both international and non-international armed conflicts. ${ }^{121}$

2 If the UN emblem has been used and that use has not been authorised by the UN, the Rule will have been broken. However, the UN may have become a party to an armed conflict, or UN personnel or units may be taking a direct part in the hostilities. In such circumstances, the UN emblem loses its protective character and UN objects, facilities and equipment and UN personnel become lawful targets for as long as the UN remains a party to the conflict or the UN personnel continue to take a direct part in the hostilities. However, if a situation mentioned in this paragraph occurs, UN personnel who are not performing military functions will retain protected civilian status and the UN facilities and equipment that are not used for military purposes will retain protection as civilian objects. Neither may be made the object of attack.

3 So, if, for example, the UN emblem is applied to a structure without the permission of the UN, the Rule is breached, irrespective of the military or other purpose that the party to the conflict is seeking to achieve through that misuse.

\section{Improper Use of Enemy Indicators}

\section{Rule 52}

It is prohibited to make use of the flags, military emblems, insignia or uniforms of the enemy while visible to the enemy during an attack, including a nuclear attack.

1 The use of flags, military emblems, insignia ${ }^{122}$ or uniforms of an adverse party to the conflict is forbidden in the course of attacks. ${ }^{123}$ The Rule has customary law status and applies in both international and non-international armed

121 API, Article 38(2); UK Manual, para. 5.10.c; Canadian Manual, para. 605(c); AMW Manual, Rule 112(e); NIAC Manual, Commentary accompanying para. 2.3.4; ICRC Customary Law Study, Rule 6o; Rome Statute, Article 8(2)(b)(vii).

122 'Insignia' means 'distinguishing badge or emblem of military rank, office or membership' (Concise Oxford English Dictionary, 11th ed. (2006), 735).

123 Hague Regulations, Article 23(f); API, Article 39(2). 
conflicts. ${ }^{124}$ The authors share the position taken in the Tallinn Manual that the Article 39(2) extension of the prohibition beyond use during attacks to actions intended to shield, favour, protect or impede military operations, while binding on States that are parties to API, does not reflect customary law. ${ }^{125}$

2 The focus of the Rule is on visible indicators of enemy status and will include national markings on military aircraft and other platforms. Consider a situation in which a State is planning to undertake an air attack against an adverse party's missile production facility that is defended by effective anti-air defences. The planners appreciate that if they apply the enemy's national and military markings to the aircraft and use call signs and other indications tending to show that the aircraft has enemy character, there is a greater chance of the attack aircraft reaching the target and conducting a successful attack. The use of the enemy military emblems will, however, breach the Rule. ${ }^{126}$

3 The authors take the view that, in the kind of context referred to in the previous paragraph, the words 'while visible to the enemy' should be interpreted somewhat broadly. The markings on the aircraft will be visible to the adversary in the likely event that the attacking aircraft is intercepted by enemy combat aircraft. In the view of the present authors, this would suffice for the marks to be regarded as 'visible to the enemy', irrespective of whether an intercepting aircraft is actually scrambled.

4 There is an important distinction between conduct that breaches the Rule - namely, the misuse of enemy visual emblems, insignia, etc. - and the use of lawful ruses, such as feigning enemy authorship of electronic or radio communications; using the enemy's signals, passwords, radio code signs and words of command; and pretending to communicate with non-existent troop formations. So, while, in the example given in paragraph 2, the use of the false flags and aircraft markings would breach the present Rule, the sending, say, of false communications from enemy commanders to air defence units instructing them not to fire on the aircraft undertaking the attack would be a lawful ruse, provided that the fake communications do not suggest a requirement to give, or an entitlement to receive, protection under LOAC.

5 If a party to the conflict is seeking to prevent or impede a nuclear attack by the adverse party, the present Rule will prohibit it from using enemy flags,

124 US DoD Law of War Manual, para. 5.23; UK Manual, para. 5.11; Canadian Manual, para. 607; German Manual, para. 473; AMW Manual, Rule 112(c); NIAC Manual, para. 2.3.5; ICRC Customary Law Study, Rule 62; Rome Statute, Article 8(2)(b)(vii).

125 The US DoD Law of War Manual, para. 5.23.1.3, finds the use of enemy flags, insignia, and military uniforms 'outside of combat' to be legitimate. See also Tallinn Manual 2.o, Commentary accompanying Rule 126, para. 2; Canadian Manual, para. 607.

126 Note that the aircraft will also, by showing false markings, not have belligerent rights. 
military emblems, insignia or uniforms while doing so. Accordingly, the State seeking to prevent or impede the attack cannot paint its enemy's flag on the roof of expected targets, but is permitted to use ruses of the sort mentioned in the previous paragraph and in the Commentary accompanying Rule 49.

6 In the conduct of maritime operations, a warship - which, for these purposes, would include a submarine - may fly the flag of an enemy or neutral State, provided that it exhibits its true, national flag immediately before an armed engagement. ${ }^{127}$ The term 'an armed engagement' would for these purposes include, for example, the firing of a nuclear armed missile or a conventional attack on a nuclear facility. So, before firing such a missile or undertaking such an attack, the submarine would be required to fly or otherwise show its correct national flag or military emblem. It is important to stress that this is not an outdated formality having no practical relevance in modern armed conflicts, in particular in nuclear operations at sea. It is not necessary for the showing of the true flag to be communicated to or noticed by the enemy or the (lawful) target. The reason for showing the true flag lies in the prohibition of privateering, which limited the exercise of belligerent rights to warships proper. Accordingly, the obligation makes it sufficiently apparent to the warships of neutral States that the attack is not a prohibited act of privateering.

7 The Rule will also have implications for the clothing worn by the crew of a military aircraft engaged in a nuclear attack or operation. During an airborne attack, the outer markings of the attacking aircraft satisfy the requirements of the Rule. If, however, in the event of being shot down, members of the crew plan to make use of enemy uniforms while undertaking attacks in the course of their attempts to escape, this action would breach the present Rule.

\section{Improper Use of Indicators of Neutrality}

\section{Rule 53}

It is prohibited to make use of flags, military emblems, insignia or uniforms of neutral or other States not party to the conflict.

1 The Rule is based on Article 39(1) of API and has customary law status. It applies in international armed conflicts. ${ }^{128}$ The applicability of the Rule to

127 San Remo Manual, para. 110.

${ }_{128}$ US DoD Law of War Manual, para. 5.24.1; UK Manual, para. 5.11; Canadian Manual, para. 6o6; German Manual, para. 473; AMW Manual, Rule 112(d); ICRC Customary Law Study, Rule 63. The exception to the Rule in naval warfare is discussed in the Commentary accompanying Rule 52, para. 6. 
non-international armed conflicts is unclear. The reference to neutrality does not apply to such conflicts. The notion of States not being party to a noninternational armed conflict does make sense, however, and it is unsettled whether the Rule applies to that extent. ${ }^{129}$

2 So, consider an adapted version of the scenario discussed in paragraph 2 of the Commentary accompanying Rule 52. The attacking State seeks to overcome the problem posed by the adversary's effective anti-air defences by applying to the aircraft the national and military markings of a neutral or nonparty State and by using call signs and other indications tending to show that the aircraft undertaking the nuclear attack has neutral or non-party status. It does this in the belief that there is a greater chance of the attack aircraft reaching the target and conducting a successful attack. If the situation arises in the context of an international armed conflict, the use of the neutral nationality and military emblems will breach the present Rule. If the same situation were to arise in the context of a non-international armed conflict, it is unclear whether the Rule would apply.

3 Other aspects of the law of neutrality are addressed in Rules 65-8.

\section{Zones}

1 Military doctrine provides for zones to fulfil a number of military purposes. Exclusion zones may be established in international waters and in the superjacent airspace to such waters. An exclusion zone can be regarded as the three dimensional space beyond the territorial sovereignty of any State in which a Belligerent Party claims to be relieved from certain provisions of the law of international armed conflict, or where that Belligerent Party purports to be entitled to restrict the freedom of aviation (or navigation) of other States'. ${ }^{130}$ A no-fly zone may be established in national airspace and, as the name implies, is a three-dimensional space in which a belligerent party restricts or prohibits aviation. The no-fly zone may be established in a party's own airspace or in the airspace of an adversary. ${ }^{131}$ Neither an exclusion zone nor a no-fly zone constitutes a 'free-fire zone' in which an intruding aircraft or, in the former case, ship can be attacked on sight and without deliberation or precaution. During an armed conflict, the principles and rules on distinction, discrimination, proportionality and precautions apply within exclusion and no-fly zones, as they do outside them. 'Neutral, civilian and other protected

129 Tallinn Manual 2.0, Commentary accompanying Rule 127, para. 2.

130 AMW Manual, Commentary accompanying Section P, para. 3.

${ }^{131}$ AMW Manual, Section P, para. 4. 
objects or persons retain their protection under [LOAC] when they enter such zones, even if they have ignored the instructions issued by the party that established them.132

2 If, during an armed conflict, a civilian aircraft or merchant vessel enters an exclusion zone or if a civilian aircraft flies within a no-fly zone, this may be an indication that the vessel or aircraft is a military objective. Equally, it may be the case, for example, that the crew of the vessel or aircraft is simply lost, that there is some kind of fault with the navigation systems or that the aircraft is in distress. The State that established the zone must not simply assume that the vessel or aircraft is in fact a military objective, but vessels and aircraft that have become military objectives can be made the object of attack. Appropriate steps must be taken to verify whether the vessel or aircraft is indeed making an effective contribution to military action and whether using force against it will, in the circumstances, be lawful.

3 If the intruding aircraft is a civilian airliner, it should be borne in mind that civilian airliners are civilian objects and that particular care must be taken when exercising the precautions required by Rules $39-46 .{ }^{133}$ In case of doubt as to whether a civilian airliner has become a military objective, the civilian airliner must be presumed not to be making an effective contribution to military action, and thus not to be a military objective. This, however, applies only if the civilian airliner is normally exclusively dedicated to civilian purposes. ${ }^{134}$ The crews of civilian airliners, irrespective of their State of registration, should avoid entering a no-fly or exclusion zone or the immediate vicinity of hostilities, but such aircraft do not lose their protected status merely by entering such zones. ${ }^{135}$ Similar considerations apply in the case of merchant vessels.

4 A party to an armed conflict may therefore establish exclusion and no-fly zones (e.g. to prevent intrusions into the vicinity of nuclear weapon launch facilities or platforms). Such zones may need to be of a sufficient size to enable proper targeting decisions to be made before force is used. Moreover, while intrusion is not, per se, sufficient to characterise a civilian vessel or aircraft as a military objective, the apparently deliberate penetration of a zone by a vessel or aircraft, when considered in conjunction with other more specific information, may tend to help to

\footnotetext{
132 Tallinn Manual 2.o, Commentary accompanying Section 9(B), para. 1, pp. 507-8.

133 AMW Manual, Rule 58 and accompanying Commentary.

134 AMW Manual, Rule 59 and accompanying Commentary.

135 AMW Manual, Rule 6o.
} 
confirm that the merchant vessel or civilian aircraft is involved in some way in the conduct of military operations, such as an attack.

\section{Persons and Objects Entitled to Specific Protection under the Law of Armed Conflict}

LOAC grants general protection to civilians and civilian objects. However, there are also specific rules protecting certain classes of person and object. In some cases, those specific rules in effect grant a level of protection that does not differ from that accorded generally to civilians and civilian objects. Where that situation exists, the protection is referred to in this book as 'specific protection'. In other cases, the particular class of person or object is granted legal protection that exceeds that given generally to civilians and civilian objects. In those circumstances, the enhanced protection is referred to in this book as 'special protection'.

During periods of armed conflict, the parties to the conflict may reach special agreements that may either grant protection to persons or objects not otherwise protected by LOAC or grant to protected persons and/or objects protection which exceeds that granted by the applicable law. The Rules set forth below reflect the protection granted to the objects and persons referred to therein under LOAC. Agreements between the parties to the conflict cannot diminish that level of legal protection. ${ }^{136}$ Such an inter-party agreement might of course provide that nuclear weapons shall in no circumstances be used by either party, might limit the circumstances in which such weapons might be employed or might prescribe agreed arrangements with a view to ensuring that no resort will be made by either side to such weapons. Such provision would have a protective effect going far beyond the specific and special protection afforded by the Rules in this Section.

Some classes of individual and object that enjoy specific or special protection under LOAC are not discussed in any detail in the following Rules. This does not mean that the protection the law gives such persons and objects is unimportant but, rather, that the provision in question is considered by the authors as being of limited relevance in the context of this book.

${ }^{136}$ GCI, GCII, GCIII, common Article 6; GCIV, Article 7; GCI, GCII, GCIII, GCIV, common Article 3; AMW Manual Rule 99 and accompanying Commentary; Tallinn Manual 2.0, 512, para. 2 . 


\section{Medical and Religious Personnel, Medical Units and Transports}

\section{Rule 54}

Medical and religious personnel, medical units and medical transports must be respected and protected and, in particular, may not be made the object of attack, including nuclear attack.

1 This Rule applies in international and non-international armed conflicts and is a rule of customary international law. ${ }^{137}$

2 During bombardments, 'all necessary steps must be taken to spare, as far as possible, ... hospitals, and places where the sick and wounded are collected, provided they are not being used at the time for military purposes'. ${ }^{138}$

3 Medical units comprise civilian or military establishments or units that are organised for medical purposes. The term therefore includes fixed or mobile units, hospitals, medical depots and medical and pharmaceutical stores, whether of a permanent or temporary nature. Medical transports encompass land, sea and air transportation of wounded, sick or shipwrecked persons, medical or religious personnel and equipment or medical supplies. Similar protections also apply to hospital ships, rescue craft and medical aircraft. Indeed, it should be borne in mind that medical aircraft may be being operated as flying clinics.

4 The 'respect' and 'protect obligations' are distinct duties. 'The duty to respect is breached by actions that impede or prevent medical or religious personnel, medical units, or medical transports from performing their medical or religious functions, or that otherwise adversely affect the humanitarian functions of medical or religious personnel, units or transports. ${ }^{139}$ It includes a prohibition on making the stated personnel, units or transports the object of attack, but does not extend to incidental effects, such as may arise as a result of an attack the object of which is a military objective. ${ }^{140}$

5 The 'respect' part of the Rule therefore prohibits making a hospital, medical clearance station, medical unit or medical transportation facility the object of an attack through the use of either a conventional or a nuclear weapon. However, if a nuclear attack is directed at a military objective such as the enemy's land-based missile launch facility, the mere fact that a medical unit is located nearby and will be destroyed will not cause this Rule to be

\footnotetext{
137 GCI, Articles 19, 24, 25, 35, 36; GCII, Articles 22, 24, 25, 27, 36-9 and Chapter 4 generally; GCIII, Article 33; GCIV, Articles 18-22; API, Articles 12, 15, 21-4, 26; APII, Article 9.

${ }_{13} 8$ Hague Regulations, Article 27.

139 Tallinn Manual 2.0, Commentary accompanying Rule 131, para. 5; AMW Manual, Commentary accompanying Rule 71, para. 12.

140 Tallinn Manual 2.0, Commentary accompanying Rule 131, para. 5.
} 
broken, although such incidental consequences must be taken into account when proportionality and precautions rules are being considered.

6 The 'protect' part of the Rule requires the taking of suitable precautions to ensure that others respect the protected facilities, transports and personnel. ${ }^{141}$

\section{Identification}

\section{Rule 55}

All feasible steps must be taken to ensure that the protected status of medical and religious personnel, medical units and medical transports is clearly indicated, although failure to do so does not deprive them of their protected status.

1 This is a customary law rule that applies in international and noninternational armed conflicts. ${ }^{1{ }^{2}}$ The language 'all feasible steps' indicates that parties to the conflict must do everything that is practically possible to ensure that the persons and objects that are protected by this Rule are appropriately marked. What is appropriate will depend on the nature of the perceived threat. If that threat includes attack from the air, the emblem should be marked, to the degree possible, so that, if the medical facility itself can be seen, the protective emblem will also be apparent.

2 The distinctive emblems of the Red Cross, Red Crescent and Red Crystal will often be used as the means of indicating the protected status of the persons and objects referred to in this Rule. It is the medical or religious function being fulfilled by the medical or religious personnel, units and transports that confers protected status. ${ }^{143}$ The use of the emblem is merely to facilitate identification of persons and objects that are entitled to that protected status. ${ }^{144}$ If the personnel, units and transports referred to in this Rule do not display the protective emblem, this does not deprive them of their protected status. ${ }^{145}$

141 AMW Manual, Commentary accompanying Rule 71, para. 13.

${ }_{142}$ Hague Regulations, Article 27(2); API, Article 18; APII, Article 12; GCI, Article 42; GCII, Articles 43, 44; GCIV, Articles 18, 20-2; US DoD Law of War Manual, para. 5.14.4; UK Manual, paras. 7.23-7.23.3; Canadian Manual, paras. 915-17; German Manual, paras. 635, 638; AMW Manual, Rule 72(a) and chapeau to Section K; NIAC Manual, Commentary accompanying para. 3.2. Note that supplementary electronic markings are provided for in API, Articles 8(m) and $18(5)$.

143 AMW Manual, Commentary accompanying Rule 72(c), para. 1.

144 API, Annex I, Article 1; APIII, preamble, para. 4.

145 AMW Manual, Rule $72(\mathrm{~d})$. 


\section{Loss of Protection and Warnings}

\section{Rule 56}

The protection to which medical and religious personnel, medical units and medical transports are entitled does not cease unless they commit, or are used to commit, outside their humanitarian function, acts harmful to the enemy. Protection may cease only after a warning has been given setting a reasonable time limit, and after such warning has remained unheeded.

1 This is a customary law rule that applies in both international and noninternational armed conflicts. ${ }^{16}$

2 Acts are harmful to the enemy if they have the harmful purpose or effect of facilitating or impeding military operations. So, an act may be harmful by impeding enemy military operations or it may be harmful by enhancing the acting party's own military operations. ${ }^{147}$ The Rule thus not only refers to acts that cause direct harm to the enemy (e.g. by directing attacks at the enemy) but also extends to activities that adversely affect military operations (e.g. by gathering military intelligence or corrupting military communications). ${ }^{14}$

3 Certain situations do not deprive the medical unit or transport of the protection afforded by Rule 55, namely:

That the personnel of the unit or establishment are armed, and that they use the arms in their own defence, or in that of the wounded and sick in their charge. ${ }^{149}$

That in the absence of armed orderlies, the unit or establishment is protected by a picket or by sentries or by an escort. ${ }^{150}$

That small arms and ammunition taken from the wounded and sick and not yet handed to the proper service, are found in the unit or establishment. ${ }^{151}$

That the humanitarian activities of medical units and establishments or of their personnel extend to the care of civilian wounded or sick. ${ }^{152}$

146 Hague Regulations, Article 28; GCI, Articles 21, 22; GCII, Articles 34, 35; GCIV, Article 19; API, Article 13; APII, Article 11(2); UK Manual, para. 7.13.1; Canadian Manual, paras. 447, 918; German Manual, paras. 613, 618-19; AMW Manual, Rule 74(a) and (b); NIAC Manual, para. 4.2.1; ICRC Customary Law Study, Rules 25, 28, 29.

147 Consider API and APII Commentaries, paras. 550, 4720; AMW Manual, Commentary accompanying Rule $74(\mathrm{a})$, para. 3 .

${ }_{148}$ Tallinn Manual 2.0, Commentary accompanying Rule 134, para. 2.

149 GCI, Article 22(1).

150 GCI, Article 22(2).

151 GCI, Article $22(3)$.

152 GCI, Article 22(5). 
That members of the armed forces or other combatants are in the unit for medical reasons. ${ }^{153}$

4 If circumstances arise that justify ending the protected status of a medical unit or establishment in accordance with this Rule, a warning must be given setting forth the nature of the misuse that is occurring and stating, where appropriate, a reasonable time limit for the warning to be complied with. The warning may be communicated to the adverse party by electronic means, by radio or televised message, by press release or by other similar means. It may simply consist of an order to terminate the harmful activity within the specified period. ${ }^{54}$

5 Even if the warning is unheeded and an attack is to be undertaken, the principle of discrimination and the rules on proportionality and precautions in attack must be complied with.

6 So, consider the situation that might arise if State A has nuclear weapons and decides to disperse its holdings of the weapons. If its enemy, State B, finds out that a nuclear device is being stored within one of State A's hospital compounds, such action would fall outside the humanitarian function of the hospital and would, self-evidently, be harmful to State B. In such a scenario, the difficult decision confronting State B is whether it is feasible for it to set a time limit for compliance. Giving a warning with such a time limit will, potentially, give State A the opportunity to conceal the weapon elsewhere and may deprive State B of an opportunity to neutralise the nuclear weapon in some way. In such a situation, State B may be able to argue that the misuse of the medical facility is causing immediate and serious harm such that no reasonable time limit needs to be set for compliance. The alternative interpretation would be that it is the potential removal of the weapon to an unknown location, rather than the continued presence of the device in the hospital compound, that would cause immediate serious harm. Before undertaking an attack, the proportionality rule must be carefully applied and all appropriate precautions taken to minimise civilian casualties and damage and casualties and damage to specially protected persons and objects.

153 API, Article 13(2)(d).

154 AMW Manual, Commentary accompanying Rule 74(b), para. 2. As pointed out in paragraphs 3 and 4 of the Commentary accompanying Rule $74(\mathrm{~b})$, the time limit must be reasonable, so as to give an opportunity for the relevant acts to be stopped or to allow for the removal of the wounded and sick from the medical facility before the attack takes place. Sometimes insisting on immediate compliance may be reasonable. It has been suggested that if the misuse is causing immediate serious harm, "it will typically not be feasible to afford an opportunity for compliance' (Tallinn Manual 2.0, Commentary accompanying Rule 134, para. 6). 
7 Loss of protection may also be the consequence of non-compliance with the conditions of protection, such as non-impartial assistance to victims. Such an activity would not be harmful to the enemy, so the aircraft or ship that is rendering such assistance may not be attacked but, for example, will lose its protection from capture.

8 If a medical establishment is being used for purposes that deprive it of its protection in accordance with this Rule, it is most unlikely that a nuclear weapon would be considered for a subsequent attack. The legal obligation to minimise civilian casualties and damage suggests that a precision munition that will limit its damaging effect as reliably as possible to the part of the compound that is actually being misused should be chosen. However, in the example given in paragraph 6, the target, a nuclear weapon, is of such a nature as to likely cause extensive collateral damage if attacked.

\section{United Nations Personnel, Installations, Materiel, Units and Vehicles}

\section{Rule 57}

It is prohibited to direct attacks, including nuclear attacks, against UN personnel for such time as the UN is not a party to the conflict and provided that they are entitled to protection as civilians. It is prohibited to direct attacks, including nuclear attacks, against materiel, installations, units and vehicles of the UN unless they are military objectives.

1 This Rule applies to international and non-international armed conflicts and has customary law status. ${ }^{155}$ Article 7 (1) of the UN Safety Convention provides: 'United Nations and associated personnel, their equipment and premises shall not be made the object of attack or of any action that prevents them from discharging their mandate.' UN personnel, materiel, installations, units and vehicles are permitted to display the UN emblem, and use of that emblem without the permission of the UN is prohibited (see Rule 51). However, when UN personnel take a direct part in hostilities or when UN materiel, installations, units or vehicles become military objectives, they lose their protection from being made the object of attack. ${ }^{156}$

155 Convention on the Safety of United Nations and Associated Personnel, New York, 9 December 1994 (UN Safety Convention), Article 7(1); Rome Statute, Article 8(2)(b)(iii) and 8(2)(e)(iii); UK Manual, paras. 14.9, 14.15; NIAC Manual, para. 3.3; ICRC Customary Law Study, Rule 33.

${ }_{15}$ AMW Manual, Commentary accompanying Rule 98b, para. 2. 
2 'United Nations personnel' comprise:

(i) Persons engaged or deployed by the Secretary-General of the United Nations as members of the military, police or civilian components of a United Nations operation; (ii) Other officials and experts on mission for the UN or its specialized agencies or the International Atomic Energy Agency who are present in an official capacity in the area where a United Nations operation is being conducted. ${ }^{157}$

$3 \mathrm{UN}$ personnel are protected from attack so long as the UN is not a party to the conflict and so long as UN personnel do not take a direct part in the hostilities. ${ }^{158}$ If the UN is a party to an international armed conflict, its military personnel who are engaged in the fighting become combatants and may be made the object of attack. UN personnel who are engaged in the provision or distribution of relief supplies or in peacekeeping duties will retain protected status. ${ }^{159}$ Robust implementation of a peace enforcement mandate will not necessarily cause the UN to become a party to the conflict. Much will depend on the particular circumstances.

4 The protection afforded to UN materiel, units, installations and vehicles is contingent on them being entitled to the protection afforded to civilian objects by LOAC. ${ }^{160}$ If they are being used to make an effective contribution to the military action of a party to the conflict, they become lawful targets.

5 While there are, therefore, certain circumstances in which UN personnel and their units, installations, materiel and vehicles may be lawfully attacked, the authors consider it to be most unlikely - indeed, almost inconceivable - that a nuclear attack against such targets would ever be lawful, let alone that it would realistically be contemplated by a responsible State. However if, for example, UN personnel, installations, materiel, units or vehicles bearing UN emblems were to be used by a party to the conflict to conceal or protect a nuclear weapon or to conceal or protect equipment associated with the use of nuclear weapons, the personnel, installations, materiel, units or vehicles that were being used in that way would be lawful targets and could be made the object of attack on that basis, subject to the rules on distinction, discrimination, proportionality and precautions.

157 UN Safety Convention, Article 1(a).

${ }_{158}$ AMW Manual, Commentary accompanying Rule 98(b), para. 1.

159 AMW Manual, Commentary accompanying Rule 98(b), para. 5.

160 AMW Manual, Commentary accompanying Rule 98(c), para. 1. 


\section{Children}

\section{Rule $5^{8}$ \\ Conscripting or enlisting children into the armed forces or allowing them to take part in nuclear operations are prohibited.}

This Rule is customary law and applies in both international and noninternational armed conflicts. The term 'children' refers to persons under the age of fifteen years.

\section{Journalists}

\section{Rule 59}

Civilian journalists engaged in dangerous professional missions in areas of armed conflict shall be considered as civilians. They shall not be made the object of attack unless, and for such time as, they take a direct part in the hostilities.

1 This Rule is based on Article 79 of API. It applies in international and noninternational armed conflicts and has customary law status. ${ }^{161}$ Journalists, for the purposes of the present Rule, include reporters, cameramen, photographers and sound technicians. ${ }^{162}$ The term will include persons who report for online media organisations, but it is unclear whether private persons who produce material for web blogs that are not associated with the established media will be included. ${ }^{163}$

2 API explains that journalists shall be protected as such under the Conventions and this Protocol, provided that they take no action adversely affecting their status as civilians ... ' ${ }^{164}$ Journalistic equipment, including recording equipment, cameras and computers, as well as all equipment directly associated with journalistic activities, will be classed as civilian objects and will retain protection as such, unless the equipment becomes a military objective (for the definition of military objective, see Rule 34 above). Journalists and their equipment enjoy specific protection, in that they are referred to explicitly in LOAC. They do not enjoy special protection, as the

${ }_{161}$ US DoD Law of War Manual, para. 4.24.2; UK Manual, para. 8.18; Canadian Manual, paras. 313, 441; German Manual, para. 515; NIAC Manual, para. 3.10; ICRC Customary Law Study, Rule 34 .

162 See United Nations Convention on the Protection of Journalists Engaged in Dangerous Missions in Areas of Armed Conflict, UN Doc A/10147 (1 August 1975), Annex I, Article 2(a), noted in Tallinn Manual 2.0, Commentary accompanying Rule 139, para. 4 and n. 1292.

163 Tallinn Manual 2.0, Commentary accompanying Rule 139, para. 4

164 API, Article 79(2). 
level of protection they and their equipment have equates with that accorded to civilians and civilian objects.

3 Journalists lose their protection if and for such time as they take a direct part in hostilities. Journalistic investigation, collation of information and transmission of that information through broadcasting, print or other means are among the numerous routine activities of journalists. If, however, information in relation to one party to the conflict is obtained by a journalist secretively or by misrepresenting his or her identity or status with a view to communicating that information to the opposing party, such an activity might amount to espionage under LOAC. ${ }^{165}$

${ }_{4}$ Consider, therefore, a situation in which a journalist receives information about the location of the nuclear weapons belonging to a party to the conflict, the preparedness of that party's nuclear forces, the command and control arrangements that party has made with regard to its nuclear force, the location of nuclear-armed submarines belonging to that party or the targets named on that party's nuclear strike list. If, while in that party's area of military operations, the journalist made any misrepresentation as to his or her identity or status as a journalist or acted secretively when obtaining that information, the mere act of obtaining the information may cause the journalist to be accused of spying and/or to be regarded as taking a direct part in the hostilities. ${ }^{166}$

\section{Dams, Dykes and Nuclear Electrical Generating Stations}

\section{Rule 60}

To avoid the release of dangerous forces and consequent severe losses among the civilian population, particular care must be taken when undertaking attacks, including nuclear attacks, against works and installations containing dangerous forces, namely, dams, dykes and nuclear electrical generating stations, and against military objectives located in the vicinity of such works and installations.

1 Article 56 of API and Article 15 of APII prohibit attacks against the works and installations referred to in this Rule, even where they qualify as military

165 Note that a civilian journalist will be subject to the domestic law applicable in the location where he or she is reporting and will therefore be subject to the definition of espionage applied there.

166 Note that while espionage does not breach LOAC, it is a crime under the criminal law of most countries and renders the spy liable to arrest, trial and, in the event of conviction, punishment. 
objectives, if the attack may cause the release of dangerous forces and consequent severe losses among the civilian population. The API provision is subject to certain exceptions. While the two treaty provisions do not reflect customary law, ${ }^{167}$ the more modest obligation in the current Rule is considered by the authors to have customary status. ${ }^{168}$ However, States that are parties to API and APII will be bound by the treaty provisions.

2 To attack such works or installations using a nuclear weapon risks releasing two sets of dangerous forces - namely, the forces resident in the work or installation that is the target of the attack and the blast and nuclear fallout that the detonation of the nuclear weapon will release. Accordingly, a very high degree of care will be required, and in virtually all imaginable circumstances the use of a nuclear weapon against such a target would be unlawful. This is because it is accepted by all States, including those not parties to API and APII, that the prohibition of indiscriminate attacks (Rule 37) applies to all attacks, including those employing nuclear weapons. In most foreseeable circumstances, a nuclear attack on a work or installation of the sort referred to in this Rule can be expected to have indiscriminate effects. At any event, when considering which precautions are feasible, the attacker must take into account the severe dangers involved in such an attack and must accordingly maximise the precautionary measures that are taken and the care with which they are applied.

3 In deciding whether the consequent losses will be 'severe', a good faith assessment of all relevant and reasonably available information must be made. ${ }^{169}$

4 The Rule applies only to dams, dykes and nuclear electrical generating stations and to military objectives located in the vicinity of such works or installations. The Rule does not apply if the work or installation is used in regular, significant and direct support of military operations and if attacking it - say, using a conventional weapon - is the only feasible way of bringing that support to an end. If that is the case and if the work or installation is to be attacked, all feasible precautions must still be taken to avoid the release of the dangerous forces.

5 API provides for a mark to facilitate the identification of the objects that are protected by this Rule. The mark consists of a group of three bright orange circles placed on the same axis. This mark is specified in Article 16 of Annex

167 See US DoD Law of War Manual, paras. 5.13.1, 17.7.1.

168 See Tallinn Manual 2.0, Commentary accompanying Rule 140, para. 1.

169 Consider Tallinn Manual 2.0, Commentary accompanying Rule 140, para. 5. 
I to API. The absence of such a mark does not deprive the work or installation of protection under the Rule.

\section{Protection of Objects Indispensable to the Survival of the Civilian Population}

\section{Rule 61}

It is prohibited to use nuclear weapons or substances to attack, destroy, remove or render useless objects indispensable to the survival of the civilian population, for the specific purpose of denying them for their sustenance value to the civilian population or to the adverse party.

1 This Rule is based on Article 54(2) of API, is a rule of customary law applicable in international armed conflicts and is a manifestation of the customary prohibition of starvation of civilians as a method of warfare. Where non-international armed conflicts are concerned, Article 14 of APII provides: 'Starvation of civilians as a method of combat is prohibited. It is therefore prohibited to attack, destroy, remove or render useless, for that purpose, objects indispensable to the survival of the civilian population ....'

2 The key element of the Rule is the purpose with which the activity is undertaken - namely, depriving the civilian population or the adverse party of the sustenance value of the items in question. Accordingly, military operations that are undertaken to achieve a different purpose but that have the effect of depriving the civilian population or the adverse party of the sustenance value of objects indispensable to survival will not breach this Rule (but may of course breach other Rules, for example, Rule $3^{8}$ (proportionality)).

3 The treaty provisions give examples of items protected by the Rule namely, foodstuffs; agricultural areas for the production of foodstuffs; crops; livestock; drinking water installations and supplies; and irrigation works. Other items may also be indispensable to the survival of the civilian population, such as medical supplies, clothing, bedding and means of shelter. What is in fact indispensable will depend on the circumstances, including the climate, geographical location and other factors. To come within the Rule, an object must be indispensable to survival, not simply beneficial. ${ }^{170}$

4 The Rule does not apply to objects that are exclusively used to sustain members of the armed forces or, if not as sustenance, then in direct support of military action. However, action must not be taken against such objects if it

170 Tallinn Manual 2.0, Commentary accompanying Rule 141, para. 4. 
may be expected to leave the civilian population with such inadequate food or water as to cause it to starve or force it to move. ${ }^{171}$

5 Consider a decision to undertake a nuclear attack against an agricultural area for the specific purpose of destroying crops over a specified area and contaminating crops and water supplies over a wider area so that the civilian population will be deprived of food and water. Such an attack would breach this Rule. Alternatively, consider a nuclear attack the purpose of which is to destroy an industrial facility that is being used to manufacture the enemy's strategic strike missiles and other military equipment and ammunition. As a result of the attack it is to be expected that crops growing in neighbouring fields and water supplies in the vicinity will be rendered useless due to contamination. Because denial of objects indispensable to the survival of the civilian population was not the, or even a, purpose of the attack, this Rule will in this case not be breached (but consider other rules, such as Rule ${ }_{3}^{8}$ (proportionality)).

\section{Cultural Property}

Rule 62

The parties to an armed conflict must respect and protect cultural property during nuclear operations. They may only use cultural property or its immediate surroundings for military purposes in cases where military necessity imperatively so requires. The parties to an armed conflict may only direct attacks against cultural property where military necessity imperatively so requires.

1 This Rule applies to both international and non-international armed conflicts and is a rule of customary law. ${ }^{172}$

2 The Hague Cultural Property Convention defines cultural property as

movable or immovable property of great importance to the cultural heritage of every people, such as monuments of architecture, art or history, whether religious or secular; archaeological sites; groups of buildings which, as a whole, are of historical or artistic interest; works of art; manuscripts, books and other objects of artistic, historical or archaeological interest; as well as

${ }^{171}$ API, Article 54(3).

172 Hague Regulations, Article 27; Hague Convention IX, Article 5; API, Article 53; APII, Article 16; Hague Cultural Property Convention, Article 4. See also US DoD Law of War Manual, para. 5.18, second para.; UK Manual, paras. 5.25-5.26.8, 15.18-15.18.3; Canadian Manual, paras. 111, 443; NIAC Manual, para. 4.2.2; ICRC Customary Law Study, Rules 38, 39; Rome Statute, Article 8(2)(b)(ix) and 8(2)(e)(iv). 
scientific collections and important collections of books or archives or of reproductions of the property defined above. ${ }^{173}$

This definition is widely accepted as being comprehensive and as reflecting customary law. ${ }^{174}$

3 Parties to an armed conflict are required to respect and protect cultural property. ${ }^{175}$ The former obligation requires that during military operations all practically possible measures be taken to avoid harm to cultural property. ${ }^{176}$ The latter obligation requires that feasible protective measures be taken to safeguard cultural property against harm caused by others during military operations. ${ }^{177}$

4 Consider a nuclear attack against a military objective located near an archaeological site causing damage to the archaeological remains. If no consideration is given to the effect of the attack on the archaeological site and if a weapon with a reduced explosive footprint could have accomplished the military purpose of the attack, these may be relevant indicators to show that the duty to respect cultural property has not been complied with.

5 The use by a party to an armed conflict of cultural property for military purposes (e.g. to store equipment related to military nuclear operations) would constitute a breach of the second sentence of this Rule. The authors take the view that a decision to use cultural property for military purposes must be taken by the commander of a force of at least battalion size or equivalent. ${ }^{178}$ The second sentence of the Rule applies also to the immediate surroundings of cultural property, because the use of those immediate surroundings for military purposes may be expected to expose the cultural property to the risk of damage or destruction in the event of an attack. ${ }^{179}$ While the second sentence of the Rule refers to use for military purposes, it is the authors' view that any use of the cultural property or of its immediate surroundings for purposes that are likely to expose such property to the risk of damage or destruction should be avoided. Before a cultural object is used for military purposes, the emblem identifying its status as cultural property must be removed.

173 Hague Cultural Property Convention, Article 1(a). The definition also includes buildings and shelters for movable cultural property and centres containing a large amount of cultural property; see Article $1(\mathrm{~b})$ and (c).

174 UK Manual, paras. 5.25, 5.25.2; AMW Manual, Rule 1(o).

175 Hague Cultural Property Convention, Articles 4, 2 respectively.

${ }_{176}$ This duty goes wider than merely prohibiting attacks on cultural property. See UK Manual, para. 5.25.3; German Manual, para. 903; AMW Manual Rule 95(c).

177 AMW Manual, Rule 94; Tallinn Manual 2.0, Commentary accompanying Rule 142, para. 3.

${ }_{178}$ In this regard, they share the view of the majority of the AMW experts; see AMW Manual, Commentary accompanying Section N(II)(i), para. 1.

179 AMW Manual, Commentary accompanying Rule 93(a), para 1. 
6 In order to facilitate the identification and protection of cultural property in territory under their control, parties to the conflict should mark it with the internationally recognised emblem and should provide the enemy with appropriate information as to its location. If such measures have not been taken, this does not deprive the cultural property of its protected status during international armed conflicts. ${ }^{180}$

7 An attack may be directed at cultural property only if military necessity imperatively so requires. ${ }^{181}$ So, if the military purpose can be achieved by taking some alternative action that does not involve attacking the cultural property, that alternative action must, other things being equal, be preferred. It is only if attacking the cultural property is imperatively required that it should be considered, subject to taking all required precautions with a view to avoiding, and in any event to minimising, the damage that the cultural property actually suffers. A decision to attack cultural property must be taken at an appropriate level of command; an effective advance warning should be given; and the attack should proceed only if the warning has gone unheeded. ${ }^{182}$

8 Notwithstanding the foregoing, the authors consider it unlikely - perhaps, inconceivable - that a responsible party to an armed conflict would actually consider using, let alone actually use, a nuclear weapon against cultural property 'of great importance to the cultural heritage of every people'.

\section{The Natural Environment}

The obligations that a State has in relation to the natural environment during times of armed conflict will vary depending on whether the State is a party to API, whether it is a party to the Environmental Modification Convention and whether, in the case of API, the State made a relevant statement on ratification of the treaty. As will be immediately evident, this situation results in differing legal obligations among States, and some of those differences have particular relevance to the use of nuclear weapons. In order to present the legal position

\footnotetext{
180 AMW Manual, Rule 94.

${ }_{181}$ See Hague Cultural Property Convention, Articles 4(2), 11(2). The AMW Manual, Rule 95(b), applies this part of the Rule to the immediate surroundings of cultural property. The present authors do not believe, as a matter of lex lata, that an attack on a military objective in the immediate vicinity of cultural property is permissible only in the case of imperative military necessity. However, the expected destruction or damage to the cultural property must be carefully assessed and reflected in the proportionality assessment that is made, as is acknowledged by the authors of the AMW Manual in Rule 95(c) thereof.

${ }_{182}$ AMW Manual, Rule 96.
} 
as clearly as possible, the opening words of each of the Rules below will seek to make it clear which group of States is affected by that Rule.

Certain comments apply to both of the following Rules relating to the natural environment. For present purposes, there is no generally agreed definition of 'natural environment'. ${ }^{3}{ }^{83}$ However, it is clear that the use of the word 'natural' shows that the term does not include environmental features that are made by humans, and it is similarly clear that ecosystems will form part of the natural environment. ${ }^{184}$ For practical purposes, it can be interpreted as meaning the biological environment in which the population is living, which would extend to fauna, flora and climatic elements.

\section{Natural Environment: The Rule under API}

\section{Rule $6_{3}$}

For States that are parties to Additional Protocol I and that did not make a statement that applies to Articles 35(3) and 55 of that treaty, it is prohibited to employ methods or means of warfare which are intended, or which may be expected, to cause widespread, long-term and severe damage to the natural environment and thereby to prejudice the health or survival of the population.

1 As the opening language indicates, this Rule binds States that are parties to API and that made no statement in relation to Articles 35(3) and 55 of the treaty when becoming a party to it. The Rule blends the two provisions by adding the words 'and thereby to prejudice the health or survival of the population' at the end of the text. As to the meanings of means of warfare and methods of warfare, see Rule 69.

2 If the intention is to cause the prohibited environmental damage and if the relevant means or method is indeed employed, the Rule will have been breached, irrespective of whether the prohibited damage in fact materialises. The words 'which may be expected' are clearly intended to introduce a degree of objectivity into the treaty provision and thus into the present Rule. The terms 'widespread, long-term and severe' are not defined in API. The API Commentary observes:

The time or duration required (i.e. long-term) was considered by some to be measured in decades. Some representatives referred to twenty or thirty years as being a minimum period. Others referred to battlefield destruction in

183 AMW Manual, Commentary accompanying Section M, para. 6; Tallinn Manual 2.0, Commentary accompanying Rule 143, para. 3 .

${ }^{184}$ AMW Manual, Commentary accompanying Section M, para. 6. 
France in the First World War as being outside the scope of the prohibition .... It appeared to be a widely shared assumption that battlefield damage incidental to conventional warfare would not normally be proscribed by this provision. What the article is primarily directed to is thus such damage as would be likely to prejudice, over a long term, the continued survival of the civilian population or would risk causing it major health problems. ${ }^{185}$

3 It should be noted that all three aspects - widespread, long-term and severe must be present for the Rule to be broken. Accordingly, if a State to which this Rule applies were to use a nuclear weapon, thereby causing nuclear contamination that is spread far and wide, that will poison the environment for decades and that prejudices the survival and health of the civilian population, it will have breached this Rule.

\section{Natural Environment: The Customary Law Rule}

\section{Rule 64}

The following rules apply to all States, including those that are parties to API but that made a statement on ratification of the treaty excluding the application to nuclear weapons of the new rules introduced by the treaty. The natural environment is a civilian object except when a portion of it becomes a military objective. The use of a nuclear weapon to cause wanton destruction of the natural environment is prohibited. When planning, ordering or conducting nuclear operations, constant care must be taken to spare the natural environment.

1 A number of States made statements when ratifying API to the effect that the new rules introduced by the treaty will not apply for such States in relation to nuclear weapons. Articles $35(3)$ and 55 of API are widely recognised as being new rules introduced by API. Therefore, for States that made the relevant statements, Articles 35(3) and 55, and by extension Rule 63 of this book, do not apply to the use of nuclear weapons. This has the further effect that such States are bound only by the customary LOAC rules relating to the natural environment.

2 The provisions in the second, third and fourth sentences of this Rule bind all States. For States that ratified API without making a 'nuclear statement', this Rule applies in addition to Rule 63. For States that ratified subject to a nuclear statement and for States that are not parties to API, this Rule sets forth the law that protects the natural environment in times of armed conflict.

185 API Commentary, para. 1454. 
The provisions of this Rule apply in international and non-international armed conflicts. ${ }^{186}$

3 When ratifying API, the United Kingdom made the following statement:

It continues to be the understanding of the United Kingdom that the rules introduced by the Protocol apply exclusively to conventional weapons without prejudice to any other rules of international law applicable to other types of weapons. In particular, the rules so introduced do not have any effect on, and do not regulate or prohibit the use of, nuclear weapons. ${ }^{187}$

4 The rules referred to in this Rule apply to all States. That the natural environment is in principle a civilian object is widely accepted. As is the case with any other object, a portion of the natural environment may become a military objective if, by nature, location, purpose or use, it makes an effective contribution to military action such that its total or partial destruction, capture or neutralisation, in the prevailing circumstances, offers a definite military advantage. ${ }^{188}$ The entire natural environment will never be a military objective and, if a part of it becomes a military objective, any attack, including a nuclear attack, must be directed at that part, must be reasonably limited to that part and must comply with the targeting law rules, so far as relevant, set forth in this Section. If an attack may be expected to cause incidental damage to the natural environment, that incidental damage must be considered when the proportionality of the planned nuclear attack is considered. Constant care must be taken to protect the natural environment in general. ${ }^{189}$

5 Wanton destruction of the natural environment is prohibited. ${ }^{190}$ For this part of the Rule to be broken, the environmental destruction must be the result of a deliberate act undertaken maliciously, so the act must not be justifiable on the basis of military necessity. ${ }^{191}$

6 It would therefore be prohibited to use a nuclear weapon deliberately to target the natural environment in the knowledge that that part of the environment is not being used for military purposes, that it has not become a military objective and that the attack will not fulfil any military purpose. If a nuclear weapon is to be used to attack a military objective, the expected impact on the

AMW Manual, Commentary accompanying Section M, paras. 5, 9, 10; see also Tallinn Manual 2.0, Rule 143 and paras 1, 4, 5 of the accompanying Commentary.

Statement (a) made by the United Kingdom on ratification of API on 28 January 1998. Other NATO States made statements to similar effect.

See Rule 34 and API, Article 52(2).

See Rule 39 and API, Article 57(1).

Hague Regulations, Article 23(g); AMW Manual, Rule 88; ICRC Customary Law Study, Commentary accompanying Rule 43; Rome Statute, Article 8(2)(b)(iv) and 8(2)(e)(xii).

191 GCIV, Article 147; AMW Manual, Commentary accompanying Rule 88, para. 2. 
natural environment must be included in the collateral damage part of the proportionality evaluation when the attack is being planned or considered. In deciding whether the use of a nuclear weapon is appropriate in particular circumstances or whether an attack on a nuclear weapon facility would be lawful, the legal duty to take constant care to spare civilian objects like the natural environment must be taken carefully into account. To direct an attack against part of the natural environment deliberately and knowing that it is not a military objective constitutes the war crime of intentionally directing an attack against a civilian object; ${ }^{192}$ note that causing clearly excessive damage to the natural environment may, depending on the circumstances, also be a war crime. ${ }^{193}$

192 Rome Statute, Article 8(2)(b)(ii).

193 Rome Statute, Article 8(2)(b)(iv). 